\title{
ENERGY AND EXERGY INVESTIGATIONS OF R1234yf AND R1234ze AS R134a REPLACEMENTS IN MECHANICALLY SUBCOOLED VAPOUR COMPRESSION REFRIGERATION CYCLE
}

\author{
Shyam Agarwal ${ }^{1, *}$, Akhilesh Arora ${ }^{1}$, B.B. Arora ${ }^{1}$
}

\begin{abstract}
The aim of present work is the evaluation of mechanically subcooled simple vapour compression refrigeration system on the basis of energy and exergy analysis, and compatibility of alternative low GWP and zero ODP HFOs R1234yf and R1234ze to replace HFC 134a. A computer program has been developed in Engineering Equation solver software to compute the system performance parameters such as COP, exergetic efficiency, total exergy destruction and exergy destruction ratio. The effect of degree of subcooling $\left(5\right.$ to $\left.30^{\circ} \mathrm{C}\right)$, evaporator temperature $\left(-30^{\circ} \mathrm{C}\right.$ to $\left.15^{\circ} \mathrm{C}\right)$, effectiveness of liquid vapour heat exchanger $(0.2$ to 1.0$)$ and compressor efficiency ( 0.4 to 1.0$)$ has been investigted on the performance parameters viz. exergy desturction, exergy destruction ratio (EDR) and exergetic efficiency of the system components. The results of current analysis highlight that the R1234ze is the best alternate refrigerant considered in the analysis and can replace R134a as the COP and exergetic efficiency of R1234ze are $1.87 \%$ and $1.88 \%$ more than that of R134a for $30^{\circ} \mathrm{C}$ of subcoooling. However, R1234yf offers lower performance than R134a. The components condenser and evaporator are the sites of highest and lowest exergy destruction respectively for the refrigerants considered.
\end{abstract}

Keywords: LVHE, EDR, R1234yf, R1234ze, R134a, Exergetic Efficiency, VCR, COP

\section{INTRODUCTION}

Energy consumption in refrigeration systems, environmental issues and cost effectiveness are essential considerations in the recent scenario in order to meet the current demand of energy, sustain energy resources, protection of the environment and in access to the large number of consumers. A number of refrigeration and airconditioning applications include automotive \& super markets air-conditioning, walk-in coolers, residential refrigerators and chillers are using low GWP refrigerant R1234yf (Honeywell [20]) and some other include airdryers, beverage dispenser, vending machines, refrigerators and chillers for supermarkets \& commercial buildings are using R1234ze (Honeywell [21]). Moreover, the European Union has approved a regulation (Regulation (EU) No 517/2014 [38]) which prohibits the use of fluorinated gases with a GWP more than 150 in domestic refrigerators and freezers w.e.f. $1^{\text {st }} \mathrm{Jan}, 2015$, and in new types of mobile air-conditioning systems from January 1, 2017. Therefore the low GWP and zero ODP [Table1] alternative refrigerants R1234yf and R1234ze may be investigated as replacements of R134a however, the thermodynamic and exergetic performance should match with the existing refrigerants. Additionally, a refrigeration system with simple modifications reduces the energy consumption and running cost.

The studies to determine the performance improvement, energy efficient and cost effective vapour compression refrigeration systems have been carried out by some researchers associated to subcooling techniques i.e. wire-on-tube condenser, heat exchanger as a subcooler, expansion power recovery through an expander, integrated vapour compression refrigeration cycle, multistate compression, ejector and internal heat exchanger etc. (Azzouzi et al. [8], Yang and Yeh [52], She et al. [42, 43], Koeln and Alleyne [25], Maurizio et al. [30], Khan and Zubair [23], Staicovici [45], Xing et al.[51], Yu et al. [54]). The performance improvement of VCR cycle through LVHE is also a suggested technique of subcooling. Arora and Kaushik [3-6] carried out various energy, exergy and parametric analysis of an actual vapour compression refrigeration and vapour absorption cycle. They reported that the efficiency defect was highest in the condenser and lowest in the liquid vapour heat exchanger. COP and exergetic efficiency were higher for R-22 than R-407C and R-410A.

The exergy is a universal measure of work potential or quality of different forms of energy in relation to a given environment. The loss of exergy or irreversibility provides a generally applicable quantitative measure of process inefficiency. Analysing a multi-component system indicates the total system irreversibility distribution among the components of system (Kotas [26]). Thus the first law based energy analysis as well as first law and second law based exergy analysis is essential to evaluate the performance of a system. A number of researchers have suggested the exergy analysis and energy and exergy analysis both. Zubair et al. [56] carried out first and 
second law analysis of both two stage and mechanical subcooling refrigeration cycles with HFC-134a and predicted that most of the losses were due to the low compressor efficiency. Llopis et al. [28, 29] analysed theoretically a simplified model of $\mathrm{CO}_{2}$ trans-critical refrigeration system using a dedicated mechanical subcooling cycle. It was reported that cooling capacity and COP increased by $28.8 \%$ and $20 \%$ respectively. They have presented the five simplified two stage refrigeration system models and analysed these system for energy performance and total environmental warming impact (TEWI) analysis with low-GWP HFC, HFO and naturals refrigerants. It was reported that the future solutions might be based on low-GWP refrigerants. Numerical and experimental approach for different refrigerant combinations in mechanical sub-cooling system, vapour compressor cycle using integrated mechanical sub-cooling, simple vapour compression cycle with dedicated mechanical subcooling cycle and employing a subcooler in two stage refrigeration cycle considered by Qureshi et al. [36, 37]. She et al. [42, 43] proposed an energy efficient refrigeration system subcooled by liquid desiccant dehumidification and evaporation process. It was predicted that COP of the hybrid system was $16.3 \%$ higher than that of conventional vapour compression refrigeration system. Mota-Babiloni et al. [31-34] reviewed the recent developments in commercial refrigeration and focused on system modifications dedicated subcooling/ implementation of ejectors, trigeneration technologies (electrical, heating and cooling demand) and better evaporation conditions control. It was reported that the hydrocarbon, $\mathrm{HFO}$ and $\mathrm{CO}_{2}$ were $\mathrm{HFC}$ replacements. Additionally, analyzed and proposed various mixtures (HFCs: R32, R125, R152a and R134a and HFOs: R1234yf and R1234ze(E)) to phase out the refrigerants R134a, R404A and R410A as per EU Regulation No 517/2014. Ansari et al. [2] carried out theoretical exergy analysis of a simple vapour compression refrigeration system with a liquid vapour heat exchanger using alternative refrigerants R1234yf and R1234ze as replacements of R134a. It was highlighted that the refrigerants R1234yf and R1234ze can be good replacements of R134a. The liquid vapour heat exchanger shows lower efficiency defect value while condenser shows highest efficiency defect value. Dixit et al. $[15,16]$ carried out energy and exergy analysis of absorption-compression cascade and waste heat driven triple effect refrigeration cycles. Topal et al. [46, 47] presented case studies of poultry industry and power plant in turkey based on application of trigeneration and exergy analysis of plant. Taner et al. [48-50] carried out optimization, energy-exergy analysis and techno-economic \& cost analysis of a drying plant, model of sugar factory and turbine power plant of sugar in turkey respectively. Moreover, the energy efficient and cost saving refrigeration cycles studies include (Cecchinato et al. [11], CEATI [12]) presented the energy efficient and cost saving configurations of small, medium and large sized refrigeration and air-conditioning systems.

In recent years, the fourth generation Hydrofluoro-olefins (HFOs)-R1234yf and R1234ze are being considered as alternative to R134a. Although, R134a is a wide spread used refrigerant due to its commercial availability, similar properties to R12, less ODP value, excellent thermal stability, non toxic and non-flammability etc., it is a HFCs and has high GWP value [Table 1]. The European Union (EU) regulation is phasing out the current generation HFCs like R134a due to its high GWP and environment consequences. A number of studies have been carried out using R1234yf and R1234ze. In the notable studies, Yataganbaba et al. [53] performed exergy analysis on a two evaporator vapour compression refrigeration system using R1234yf, R1234ze and R134a as refrigerants. The two refrigerants R1234yf and R1234ze were good alternatives to R134a regarding their environment friendly properties. Sethi et al. [41] carried out tests in a representative vending machine system (cassette) at two representative outdoor ambient temperatures of $32.2^{\circ} \mathrm{C}$ (efficiency test), and $40.5^{\circ} \mathrm{C}$ (capacity test) for return air temperatures of $2^{\circ} \mathrm{C}, 20^{\circ} \mathrm{C}$ and $38^{\circ} \mathrm{C}$ using refrigerants $\mathrm{R} 1234 \mathrm{yf}$ and $\mathrm{R} 1234 \mathrm{ze}(\mathrm{E})$ as a replacement to R134a. It was predicted that the performance of R1234yf is similar to R134a while R1234ze(E) requires minor changes in the system design. Zheng and Zhao [55] proposed a two-stage heat pump (TSHP) based on the combination of vapour expander and compressor i.e. TSHP-E. Thermodynamic and economic performance comparison have been carried out for wet refrigerants R152a, R134a, R161 and R290, and dry fluids including R227ea, R1234yf and R1234ze and concluded that the COP and exergetic efficiency of TSHP-E is higher than that of single-stage heat pump (SSHP) when temperature lift was large. Devecioglu and Oruc [13] investigated properties of low GWP refrigerants R450A, R513A, R1234yf and R1234ze(E) replaced to R134a; DR-33, L40, DR-7; R448A replaced to R404A; DR-5; R447A replaced to R410A; and N20 and R444B replaced to R22. The study highlighted that all the new refrigerants are better regarding their low GWP values and R1234yf, L40, DR5 and R444B refrigerants can be good alternatives to R134a, R404A, R410A and R22, respectively. Pigania et al. [35] examined the safety, efficiency, volumetric capacity and total environmental warming impact for a marine refrigeration system using low GWP refrigerants ammonia $\left(\mathrm{NH}_{3}\right)$, carbon dioxide $\left(\mathrm{CO}_{2}\right)$, and the HFOs R1234yf 
and R1234ze(E) and predicted that the Low-GWP refrigerants may increase the system total environmental warming impact (TEWI). Five low GWP refrigerants R152a, R1234yf, R1234ze(E), R290 and R600a have been compared by Sanchez et al. [40] for the replacement of R134a on the same refrigerating test bench equipped with a hermetic compressor designed for R134a. It was predicted that R1234yf and R152a can be considered suitable drop-in alternative to R134a considering the energy consumption and the cooling capacity of refrigerating facility. On the other hand, R1234ze(E), R600a and R290 were not suitable drop-ins because these required different displacement compared to R134a. Jankovic et al. [22] analysed R1234yf and R1234ze(E) as drop-in replacement for R134a in a small power refrigeration system considering equal evaporation and condensation temperatures before and after the refrigerant replacement and for equal cooling medium conditions in the condenser. It was announced that the R1234yf was an adequate drop-in refrigerant for R134a but R1234ze might perform better when an overridden compressor can be used to match the refrigerating system cooling power. Fang et al. [19] carried out numerical and thermodynamic analysis of ejector heat driven refrigeration cycle (EHDRC) for the drop-in replacement of refrigerant R134a with R1234yf and R1234ze(E). It was reported that R1234yf appeared good drop-in replacement of R134a in a real EHDRC with decrease of 5.2\% for the entrainment ratio, 9.6\% for the COP and $19.8 \%$ for the cooling power in average. On the other hand using R1234ze(E) would induced some modifications due to its thermodynamic properties with reduced coefficient of performance (COP) and cooling power by $4.2 \%$ and $26.6 \%$ in average with better entrainment ratio.

The present energy and exergy analysis compare the R1234yf and R1234ze to R134a using a LVHE VCR cycle for different evaporator temperature, degree of subcooling, effectiveness of LVHE and isentropic efficiency of compressor. The thermodynamic and environmental properties of R134a, R1234yf and R1234ze are briefly being compared in Table 1 .

Table 1. Thermodynamic and environmental characteristics of refrigerants R134a, R1234yf and R1234ze ( ${ }^{\mathrm{P} H o n e y w e l l ~[20], ~}{ }^{\mathrm{q}}$ Honeywell [21], rNIST REFPROP version 9.0 [27], ${ }^{\mathrm{s}}$ Bitzer [10], ${ }^{\mathrm{t}} \mathrm{ANSI} / \mathrm{ASHRAE}$ standard 34 [7], "EES [24])

\begin{tabular}{|c|c|c|c|c|}
\hline \multicolumn{2}{|l|}{ Refrigerant } & $\mathbf{R 1 3 4 a ^ { p , q , r }}$ & R1234yf $^{p}$ & R1234ze $^{q}$ \\
\hline \multicolumn{2}{|l|}{ Chemical Name $^{r}$} & $\begin{array}{c}1,1,1,2- \\
\text { Tetrafluoroethane }\end{array}$ & $\begin{array}{c}2,3,3,3- \\
\text { Tetrafluoropropene }\end{array}$ & $\begin{array}{l}\text { trans-1,3,3,3- } \\
\text { Tetrafluoroprop-1- } \\
\text { ene }\end{array}$ \\
\hline \multicolumn{2}{|c|}{ Molecular formular } & $\begin{array}{c}\mathrm{CH}_{2} \mathrm{CF}_{4} \\
\left(\mathrm{CF}_{3}-\mathrm{CH}_{2} \mathrm{~F}\right)\end{array}$ & $\begin{array}{c}\mathrm{C}_{3} \mathrm{H}_{2} \mathrm{~F}_{4} \\
\left(\mathrm{CH}_{2}=\mathrm{CFCF}_{3}\right)\end{array}$ & $\begin{array}{c}\mathrm{C}_{3} \mathrm{H}_{2} \mathrm{~F}_{4} \\
\left(\mathrm{CF}_{3} \mathrm{CH}=\mathrm{CHF}\right)\end{array}$ \\
\hline \multicolumn{2}{|c|}{ Molecular mass $(\mathrm{kg} / \mathrm{kmol})^{\mathrm{r}}$} & 102.03 & 114.04 & 114.04 \\
\hline \multicolumn{2}{|c|}{ Boiling Point $\left({ }^{\circ} \mathrm{C}\right)^{\mathrm{r}}$ at $1 \mathrm{~atm}$} & -26.07 & -29.45 & -18.95 \\
\hline \multicolumn{2}{|c|}{ Freezing Point $\left({ }^{\circ} \mathrm{C}\right)^{\mathrm{p}, \mathrm{q}}$ at $1 \mathrm{~atm}$} & -103.3 & -150 & -156 \\
\hline \multicolumn{2}{|l|}{ GWP Rating ${ }^{\mathrm{p}, \mathrm{q}, \mathrm{s}}$} & 1430 & 4 & $<1$ \\
\hline \multicolumn{2}{|l|}{ ODP Rating ${ }^{\mathrm{p}, \mathrm{q}, \mathrm{s}}$} & 0 & 0 & 0 \\
\hline \multicolumn{2}{|c|}{ Critical Temperature $\left({ }^{\circ} \mathbf{C}\right)^{r}$} & 101.06 & 94.69 & 109.37 \\
\hline \multicolumn{2}{|c|}{ Critical Pressure $(\mathrm{MPa})^{\mathrm{r}}$} & 4.0593 & 3.3822 & 3.6363 \\
\hline \multicolumn{2}{|l|}{ Safety group $^{\mathrm{t}}$} & A1 & $\mathrm{A} 2 \mathrm{~L}$ & A2L \\
\hline \multicolumn{2}{|l|}{ Purity (wt.\%) } & $100 \%$ & $100 \%$ & $100 \%$ \\
\hline \multicolumn{2}{|l|}{ Appearance $^{p, q}$} & Colourless & Colourless & Colourless \\
\hline \multicolumn{2}{|l|}{ Combustibility $^{\mathrm{p}, \mathrm{q}}$} & No & Yes (Low) & No \\
\hline \multicolumn{2}{|l|}{ Corrosiveness } & No & -- & -- \\
\hline \multicolumn{2}{|l|}{ Toxicity $^{p, q}$} & No & No & No \\
\hline \multicolumn{2}{|c|}{ Thermal stability } & Excellent & Very good & -- \\
\hline \multicolumn{2}{|l|}{ Flammability $^{\mathrm{s}}$} & Non flammable & Mild flammable & Mild flammable \\
\hline \multirow{2}{*}{$\begin{array}{l}\text { Specific heat } \\
\left(\mathbf{k J} / \mathbf{k g}^{\circ} \mathbf{C}\right)^{\mathbf{u}}\end{array}$} & $\left(\mathrm{C}_{\mathrm{pv}}\right)$ at $-10^{\circ} \mathrm{C}$ & 0.8543 & 0.8849 & 0.8656 \\
\hline & $\left(\mathrm{C}_{\mathrm{pl}}\right)$ at $50^{\circ} \mathrm{C}$ & 1.566 & 1.478 & 1.505 \\
\hline \multirow{2}{*}{\begin{tabular}{|l|} 
Latent heat of \\
vaporization \\
$(\mathbf{k J} / \mathbf{k g})^{\mathbf{u}}$ \\
\end{tabular}} & $\left(h_{f g}\right)$ at $-10^{\circ} \mathrm{C}$ & 206.7 & 170.0 & 190.5 \\
\hline & $\left(h_{f g}\right)$ at $50^{\circ} \mathrm{C}$ & 151.8 & 123.4 & 145.0 \\
\hline
\end{tabular}


With the reference to the literature survey constituted from the different established database sources like Science Direct, Scopus and Research Gate etc., these valuable studies focus on the exergy analysis of VCR cycle using different refrigerants. Out of the considered research, some highlight energy efficient techniques of subcooling to VCRS and other emphasised the use of Hydrofluoroolefins (HFOs) refrigerants as alternative of current generation of Hydrofluorocarbon (HFCs). Although extensive research has been carried out to check the thermodynamic performance of traditional VCRS, and associated with energy efficient subcooling techniques using different refrigerants, as far as concern a limited number of analysis have been performed to explore the thermodynamic performance of VCR cycle employed LVHE for mechanical subcooling using HFOs and to investigate the effect of degree of subcooling, effectiveness of LVHE, isentropic efficiency of compressor and evaporator temperature on the COP, exergetic efficiency and total exergy destruction of the system and system components. In the present work, unlike the past research the energy and exergy analysis of a VCR cycle employed LVHE for mechanical subcooling using R1234yf and R1234ze as alternative to R134a have been performed for the different degree of subcooling, evaporator temperature, effectiveness of LVHE and isentropic efficiency of compressor.

The current paper consists four sections. Section 1 describes briefly the refrigerants considered for analysis and rationale of the study. In section 2, the description of VCR system employing LVHE for mechanical subcooling in detail with thermodynamic modelling dealing energy and exergy criteria has been presented. Section 3 highlights the results of energy and exergy analysis of system and system components and finally, the concluding remarks have been discussed in section 4 .

\section{SYSTEM DESCRIPTION AND MODELLING}

In the present work, a VCR cycle employed LVHE for mechanical subcooling using R1234yf and R1234ze alternative to R134a refrigerant has been investigated for energy and exergy performance. A liquid vapour heat exchanger is used to subcool the saturated liquid refrigerant leaving the condenser. Figs. 1(a) and 1(b) show the schematic and P-h diagrams of vapour compression cycle with liquid vapour heat exchanger respectively. The system comprises a compressor, a condenser, a throttle valve, an evaporator and a liquid vapour heat exchanger. The pressure-enthalpy and temperature-entropy diagrams of considered refrigerants R134a, R1234yf and R1234ze have been shown in Fig. 1(c) with the evaporator $\left(-10^{\circ} \mathrm{C}\right)$ and condenser temperature $\left(50^{\circ} \mathrm{C}\right)$. The evaporator (200.7, 221.8 and $227.4 \mathrm{kPa})$ and condenser pressure $(1319,1302,997.4 \mathrm{kPa})$ corresponding to evaporator $\left(-10^{\circ} \mathrm{C}\right)$ and condenser temperature evaporator $\left(50^{\circ} \mathrm{C}\right)$ have been notified to compare the applicability of the refrigerants R134a, R1234yf and R1234ze respectively.

Generally, commercial refrigerating units are incorporated with liquid vapour heat exchanger (LVHE) for making the advantage of mechanical subcooling to enhance the cooling capacity of the system. Mechanical subcooling is a process to subcool the saturated liquid leaving the condenser and superheat the saturated vapour leaving the evaporator. Moreover, refrigeration involves the phase change of refrigerants i.e. from vapour to liquid or liquid to vapour to absorb the heat from a colder region, temperature and pressure of refrigerant rises and finally rejected heat to a hotter region. The cold fluid (superheated vapour) is received by the compressor at state point 1a which compressed the fluid to the high pressure at state point 2a. The high pressure and temperature superheated fluid rejects its heat in the condenser from state $2 \mathrm{a}$ to 3 and a saturated liquid is obtained at state point 3. The saturated liquid refrigerant leaving the condenser (state point 3) enters into LVHE where it loses the heat to the saturated vapour refrigerant coming from evaporator. The heat exchanger subcools the saturated liquid (state point 3a, from where the subcooled liquid is expanded though a throttle valve to state $4 \mathrm{a}$ ) and saturated vapour gets superheated (state point 1a) before entering into the compressor. In the compressor the superheated refrigerant is compressed to state $2 \mathrm{a}$. The refrigeration effect is produced in the evaporator from state 4a to state 1. The effect of incorporating the LVHE in the cycle is to increase the specific refrigeration effect as well as specific compressor work. The change in COP depends upon the rate of increase of cooling capacity and compressor power. 


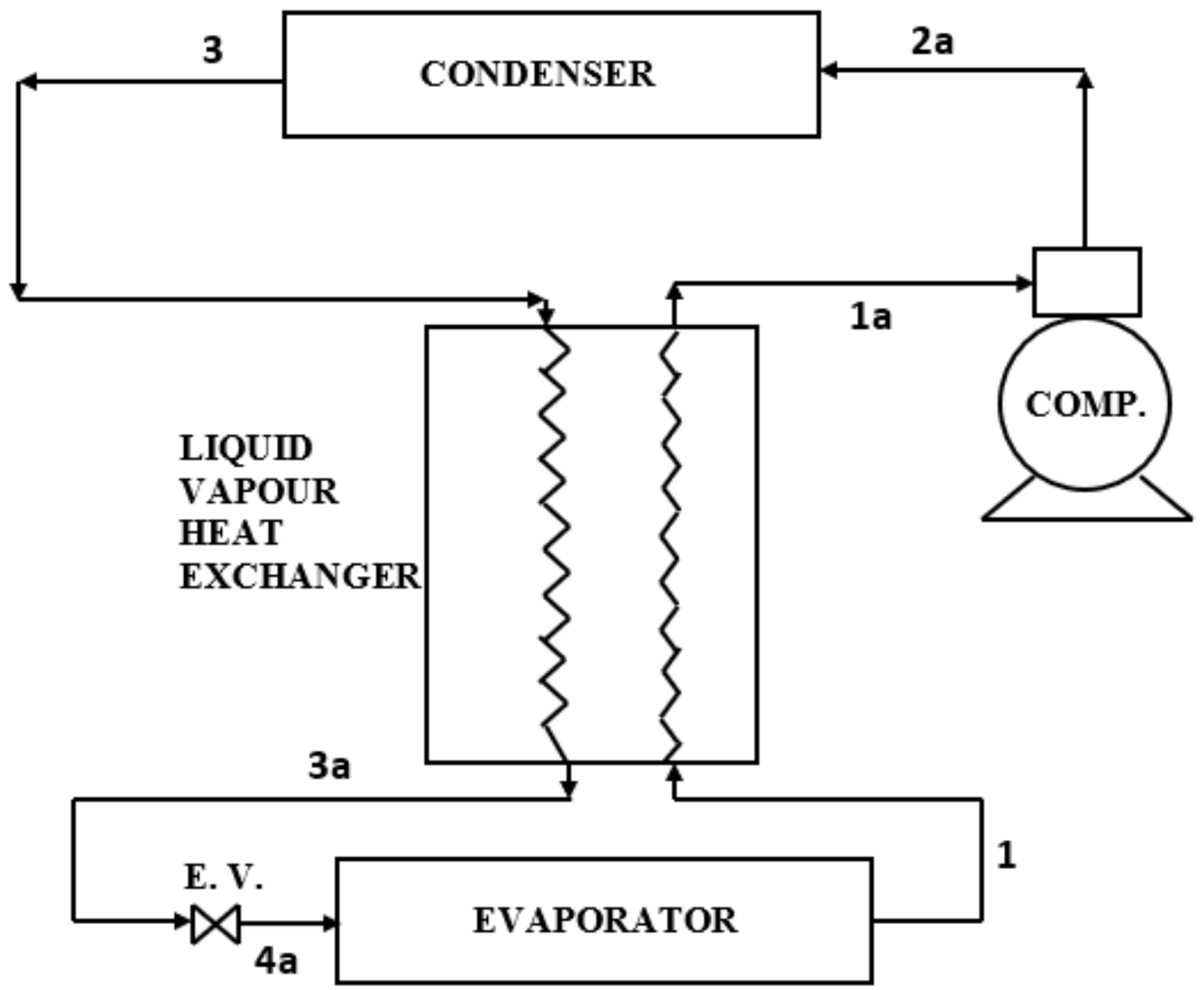

Figure 1(a). Schematic diagram of liquid vapour heat exchanger (LVHE) incorporated vapour compression refrigeration cycle

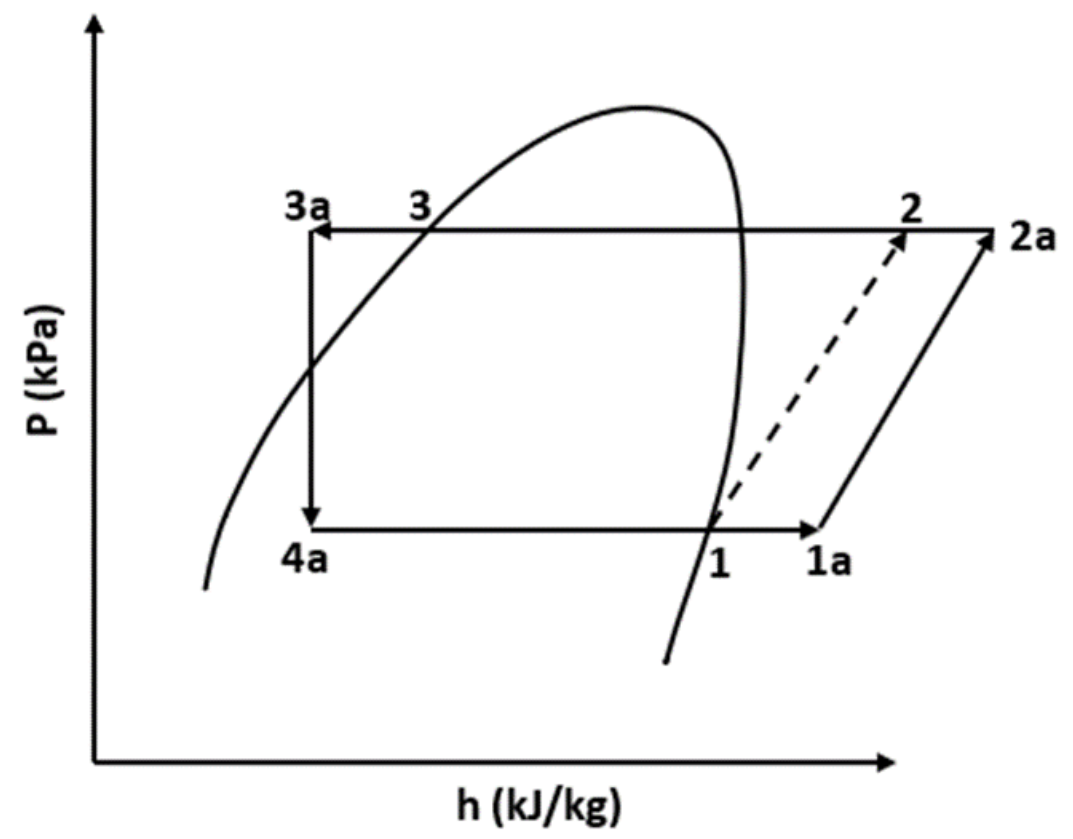

Figure 1(b). P-h diagram of LVHE incorporated vapour compression refrigeration cycle 

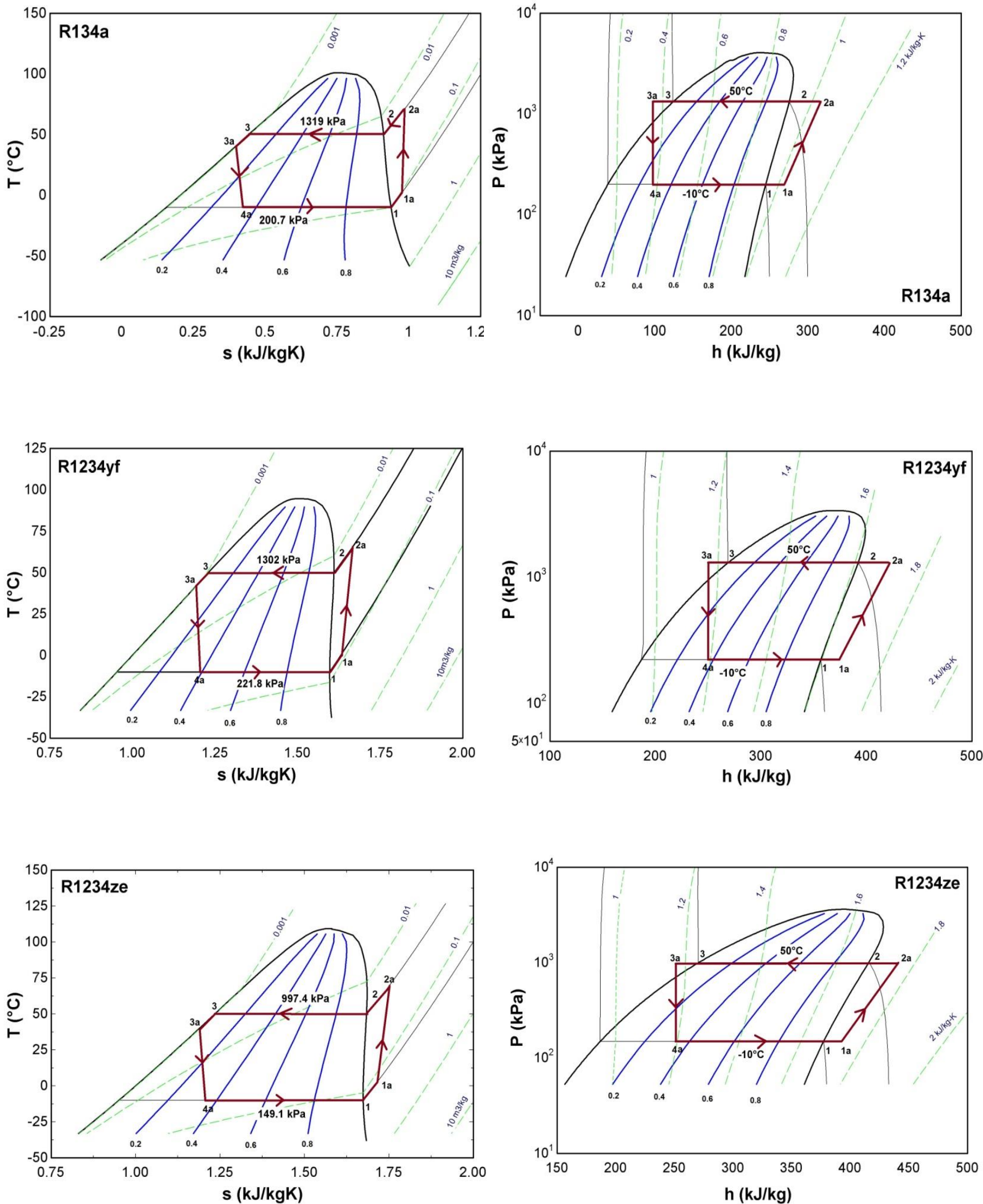

Figure 1(c). Temperature-entropy (T-s) and Pressure-enthalpy (P-h) state diagrams of R134a, R1234yf and R1234ze 


\section{Thermodynamic Modelling}

In this work, the energy and exergy performance of a LVHE incorporated VCR cycle have been analysed using R134a, R1234yf and R1234ze for different degree of subcooling, evaporator temperature, effectiveness of LVHE and isentropic efficiency of compressor. The compressor work, COP, exergetic efficiency, total exergy destruction and exergy destruction ratio of the system have been investigated and the exergetic efficiency, exergy destruction and exergy destruction ratio of each component are also explored. A computer program using EES has been prepared to evaluate effect of different parameters. The thermodynamic modelling is categorised in two sections. One is energy analysis and other is exergy analysis.

\section{Energy Analysis}

The coefficient of performance (COP) of VCR cycle with LVHE is given by the equation (1)-(3)

$$
C O P=\frac{\dot{Q}_{e}}{\dot{W}_{\text {comp }}}
$$

Where $\dot{Q}_{e}$ is the net refrigeration effect produced and $\dot{W}_{\text {comp }}$ is the actual work of the compressor.

$$
\begin{gathered}
\dot{Q}_{e}=\dot{m}_{r}\left(h_{1 a}-h_{4 a}\right) \\
\dot{W}_{c o m p}=\dot{m}_{r}\left(h_{2 a}-h_{1 a}\right)
\end{gathered}
$$

The effectiveness of liquid-vapour heat exchanger is the ratio of minimum amount of heat transfer to the maximum amount of heat transfer.

$$
\varepsilon=\frac{\dot{m}_{r}\left(c_{p}\right)_{\min }\left(T_{3}-T_{3 a}\right)}{\dot{m}_{r}\left(c_{p}\right)_{\min }\left(T_{3}-T_{1}\right)}
$$

Where $\varepsilon$ is the effectiveness of LVHE and $C_{p}$ is the specific heat capacity of flowing refrigerant.

The energy balance in the LVHE is given by equation (5)

$$
\dot{m}_{r}\left(h_{3}-h_{3 a}\right)=\dot{m}_{r}\left(h_{1 a}-h_{1}\right)
$$

\section{Exergy Analysis}

The concept of exergy is derived from the second law of thermodynamics and the exergy is defined as the maximum useful work which can be extracted from a system as it reversibly comes into equilibrium with its environment or degree measure of usefulness, quality or an effective measure of the potential of substance to impact the environment (Bejan et al. [9], Arora and Kaushik [6]).

The total exergy $(E)$ of a system is the sum of physical exergy $\left(\mathrm{E}^{\mathrm{PH}}\right)$, kinetic exergy $\left(\mathrm{E}^{\mathrm{KN}}\right)$, potential exergy $\left(\mathrm{E}^{\mathrm{PT}}\right)$ and chemical exergy $\left(\mathrm{E}^{\mathrm{CH}}\right)$ (Bejan et al. [9]).

$$
E=\left(E^{P H}\right)+\left(E^{K N}\right)+\left(E^{P T}\right)+\left(E^{C H}\right)
$$

However, due to minute speed changes and elevation, the kinetic and potential exergy are assumed to be insignificant. The chemical exergy is significant with the departure of the chemical composition of a system from its chemical equilibrium (Ahmadi et al. [1], Srinivas and Deb [44]).Therefore the physical exergy is considered in the system and the chemical exergy is supposed to be neglected as the considered refrigeration system is free from chemical reactions (i.e. combustion) or mixture of chemical substances.

For the refrigerant flowing in a refrigerating system, the exergy is defined as follows (Bejan et al. [9]):

$$
\dot{E}=\dot{m}_{r}\left[\left(h-h_{0}\right)-T_{0}\left(s-s_{0}\right)\right]
$$

Where $\mathrm{h}_{0}$ and $\mathrm{s}_{0}$ are the enthalpy and entropy values of the refrigerant at dead state pressure $\mathrm{P}_{0}$ and temperature $\mathrm{T}_{0}$. 
Exergy destruction $\left(\dot{E}_{D}\right)$ or internal exergy destruction losses which are caused by irreversibilites of the system is the algebric sum of total exergy at the inlet and outlet of the system. General exergy balance is given by Dincer and Kanoglu [14]:

$$
\dot{E}_{D}=\dot{E}_{\text {in }}-\dot{E}_{\text {out }}
$$

Where $\dot{\mathrm{E}}_{\mathrm{D}}$ is the rate of exergy destruction and $\dot{\mathrm{E}}_{\mathrm{in}}$ and $\dot{\mathrm{E}}_{\text {out }}$ are the total exergy transferred by heat, work and mass.

The steady flow process is occurring in a control volume, the exergy balance for the system is given by (Bejan et al. [9]):

$$
\dot{E}_{D}=\left[\sum \dot{Q}\left(1-\frac{T_{0}}{T_{b}}\right)_{\text {in }}-\sum \dot{Q}\left(1-\frac{T_{0}}{T_{b}}\right)_{\text {out }}\right] \pm \dot{W}+\left[\sum\left(m e_{x}\right)_{\text {in }}-\sum\left(m e_{x}\right)_{\text {out }}\right]
$$

Where $\dot{E}_{\mathrm{D}}$ is the rate of exergy desturction. The first bracket on the right side of Equation (5) is the exergy transfer associated with the transfer of energy by heat $\dot{Q}$ from the source maintained at constant boundary temperature $\mathrm{T}_{\mathrm{b}}$ which is equal to the maximum reversevible work obtained from heat transfer $\dot{Q}$ by the Carnot engine operating between $T_{b}$ and $T_{0 .}$. Where $T_{0}$ is the dead state temperature. The second bracket repesents the exergy transfer rates at control volume inlets and outlets and the $\dot{W}$ represents the time rate of exergy transfer by work other than the flow work (mechanical work) to or from the control volume.

\section{Exergy destruction ( $\left.\dot{E}_{D}\right)$ in the components of Liquid Vapour Heat Exchanger (LVHE) Vapour Compression Cycle}

The exergy destruction and exergetic efficiency in each component of the liquid vapour heat exchanger (LVHE) vapour compression cycle is given by the following equations:

\section{Evaporator}

$\left(\dot{\mathrm{E}}_{\mathrm{D}}\right)_{\mathrm{evp}}=\dot{\mathrm{E}}_{\mathrm{X}_{4 \mathrm{a}}}+\dot{\mathrm{Q}}_{\mathrm{e}}\left(1-\frac{\mathrm{T}_{0}}{\mathrm{~T}_{\mathrm{b}}}\right)-\dot{\mathrm{E}}_{\mathrm{X}_{1}}=\dot{\mathrm{m}}_{\mathrm{r}}\left(\mathrm{h}_{4 \mathrm{a}}-\mathrm{T}_{0} \mathrm{~s}_{4 \mathrm{a}}\right)+\dot{\mathrm{Q}}_{\mathrm{e}}\left(1-\frac{\mathrm{T}_{0}}{\mathrm{~T}_{\mathrm{b}}}\right)-\dot{\mathrm{m}}_{\mathrm{r}}\left(\mathrm{h}_{1}-\mathrm{T}_{0} \mathrm{~s}_{1}\right)$

\section{Compressor}

$$
\eta_{\text {ex }, \text { evp }}=1-\frac{\left(\dot{\mathrm{E}}_{\mathrm{D}}\right)_{\mathrm{evp}}}{\dot{\mathrm{E}}_{\mathrm{X} 4 \mathrm{a}}}
$$

$$
\begin{gathered}
\left(\dot{E}_{D}\right)_{c o m p}=\dot{E}_{X_{1 a}}+\dot{W}_{c o m p}-\dot{E}_{X_{2 a}}=\dot{m}_{r}\left(h_{1 a}-T_{0} s_{1 a}\right)+\dot{W}_{c o m p}-\dot{m}_{r}\left(h_{2 a}-T_{0} s_{2 a}\right) \\
\eta_{\text {ex,comp }}=1-\frac{\left(\dot{E}_{D}\right)_{c o m p}}{\dot{W}_{c o m p}}
\end{gathered}
$$

Condenser

$$
\begin{gathered}
\left(\dot{E}_{D}\right)_{\text {cond }}=\dot{E}_{X_{2 a}}-\dot{E}_{X_{3}}=\dot{m}_{r}\left(h_{2 a}-T_{0} s_{2 a}\right)-\dot{m}_{r}\left(h_{3}-T_{0} s_{3}\right) \\
\eta_{e x, \text { cond }}=1-\frac{\left(\dot{E}_{D}\right)_{c o n d}}{\dot{E}_{X_{2 a}}-\dot{E}_{X_{3}}}
\end{gathered}
$$

Throttle Valve

$$
\begin{gathered}
\left(\dot{E}_{D}\right)_{t h v}=\dot{E}_{X_{3 a}}-\dot{E}_{X_{4 a}}=\dot{m}_{r}\left(h_{3 a}-T_{0} s_{3 a}\right)-\dot{m}_{r}\left(h_{4 a}-T_{0} s_{4 a}\right)=\dot{m}_{r} T_{0}\left(s_{4 a}-s_{3 a}\right) \\
\eta_{e x, t h v}=\frac{\dot{E}_{X_{4 a}}}{\dot{E}_{X_{3} a}}
\end{gathered}
$$




\section{Liquid Vapour Heat Exchanger}

$$
\begin{gathered}
\quad\left(\dot{E}_{D}\right)_{L V H E}=\left(\dot{E}_{X_{1}}-\dot{E}_{X_{1 a}}\right)+\left(\dot{E}_{X_{3}}-\dot{E}_{X_{3 a}}\right)=\dot{m}_{r}\left(h_{1}-h_{1 a}+h_{3}-h_{3 a}\right)-\dot{m}_{r} T_{0}\left(s_{1}-\right. \\
\left.s_{1 a}+s_{3}-s_{3 a}\right) \\
\eta_{e X, L V H E}=1-\frac{\left(\dot{E}_{D}\right)_{L V H E}}{\left(E_{X_{1}}+\dot{E}_{X_{3}}\right)-\left(\dot{E}_{X_{3}}+\dot{E}_{X_{1 a}}\right)}
\end{gathered}
$$

\section{Total Exergy Destruction}

Total exergy destruction of the system is the sum of exergy destruction in each component of the system. The total exergy destruction in LVHE vapour compression cycle is given by:

$$
\sum\left(\dot{E}_{D}\right)=\left(\dot{E}_{D}\right)_{e v p}+\left(\dot{E}_{D}\right)_{c o m p}+\left(\dot{E}_{D}\right)_{c o n d}+\left(\dot{E}_{D}\right)_{t h v}+\left(\dot{E}_{D}\right)_{L V H E}
$$

\section{Exergetic Efficiency}

Exergetic efficiency is an important parameter for evaluating thermodynamic performance of a system or a system component. In general exergetic efficiency is defined as (Dincer and Kanoglu [14]):

$$
\eta_{\text {ex }}=\frac{\sum \dot{\mathrm{E}}_{\text {out }}}{\sum \dot{\mathrm{E}}_{\text {in }}}=1-\frac{\sum \dot{\mathrm{E}}_{\mathrm{D}}}{\sum \dot{\mathrm{E}}_{\text {in }}}
$$

Where $\eta_{\text {ex }}$ is the exergetic efficiency of the cycle. $\sum \dot{\mathrm{E}}_{\text {out }}, \sum \dot{\mathrm{E}}_{\text {in }}$ and $\sum \dot{\mathrm{E}}_{\mathrm{D}}$ are the total exergy recovered, supplied and destructed respectively.

The exergetic efficiency is the ratio of exery in products to the exergy of fuel. The exergetic efficiency of vapour compression refrigeration system is defined as the ratio of the exergy of heat absorbed in the evaporator from the space to be cooled at temperature $T_{b}$ to the actual compressor work input ( $\dot{W}_{\text {comp }}$ ) (Arora and Kaushik $[6])$.

$$
\eta_{e x}=\frac{\left|\dot{Q}_{e}\left(1-\frac{T_{0}}{T_{b}}\right)\right|}{\dot{W}_{c o m p}}
$$

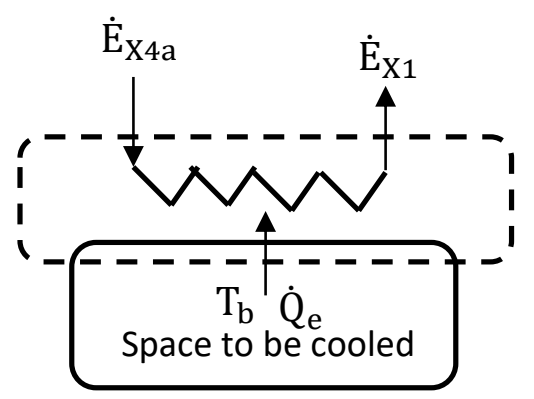

Figure 2. Exergy balance in evaporator and the space to be cooled [26]

$$
\eta_{e x}=C O P \times\left|\left(1-\frac{T_{0}}{T_{b}}\right)\right|
$$

Where $\mathrm{T}_{0}$ is the ambient or dead state temperature.

\section{Exergy Destruction Ratio (EDR)}

The EDR is the total exergy destruction in the system to the exergy in the products (Arora and Kaushik [6]) and is given by Eq. (24). 


$$
E D R=\frac{\dot{E}_{D, t o t a l}}{\dot{E}_{P}}=\frac{1}{\eta_{e x}}-1
$$

The exergy destruction ratio is the rate of exergy destruction in a system component $\left(\dot{E}_{D, i}\right)$ to the exergy rate of the fuel provided to the overall system $\left(\dot{E}_{E, \text { tot }}\right)$ or the total exergy destruction rate within the system $\left(\dot{E}_{D, \text { total }}\right)$ (Bejan et al. [9]).

$$
E D R=\frac{\dot{E}_{D, i}}{\dot{E}_{E, \text { total }}}=\frac{\dot{E}_{D, i}}{\dot{E}_{D, \text { total }}}
$$

The exergy destruction ratio in each component of the liquid vapour heat exchanger (LVHE) vapour compression cycle is given by the following equations:

\section{Evaporator}

$$
E D R_{e v p}=\frac{\left(\dot{E}_{D}\right)_{e v p}}{\dot{E}_{D, t o t a l}}
$$

\section{Compressor}

$$
E D R_{\text {comp }}=\frac{\left(\dot{E}_{D}\right)_{c o m p}}{\dot{E}_{D, t o t a l}}
$$

\section{Condenser}

$$
E D R_{\text {cond }}=\frac{\left(\dot{E}_{D}\right)_{\text {cond }}}{\dot{E}_{D, \text { total }}}
$$

\section{Throttle Valve}

$$
E D R_{t h v}=\frac{\left(\dot{E}_{D}\right)_{t h v}}{\dot{E}_{D, t o t a l}}
$$

\section{Liquid Vapour Heat Exchanger}

$$
E D R_{t h V}=\frac{\left(\dot{E}_{D}\right)_{L V H E}}{\dot{E}_{D, \text { total }}}
$$

\section{RESULTS AND DISCUSSION}

A computer program is developed in EES [24] for the model described in section 'Thermodynamic Modelling' above, to analyse LVHE associated to simple vapour compression refrigeration system using R134a, R1234yf and R1234ze on the basis of energy and exergy. The property codes for various properties are inbuilt in function directory of the EES and are called for computation of various properties such as specific enthalpy, specific entropy, specific volume, pressures and temperatues etc. The results from the present analysis have been compared with the results of Arora et al. [6]. It is observed that the difference in the value of COP and exergetic efficiency is within a range of $\pm 1 \%$. The difference in results may be due to the pressure drop in evaporator and condenser is assumed to be zero.

The following assumptions and input variables have been considered during the analyis except where the variation of physical parameters involved.

1. Net refrigerating effect $\left(\dot{Q}_{\mathrm{e}}\right)=3.5167 \mathrm{~kW}$

2. The range of variation of evaportor temperature $\left(\mathrm{T}_{\mathrm{e}}\right)=-30^{\circ} \mathrm{C}$ to $15^{\circ} \mathrm{C}$

3. Isentropic efficiency of compressor $\left(\eta_{\text {comp }}\right)=80 \%$

4. Condenser temperature $\left(\mathrm{T}_{\mathrm{c}}\right)=50^{\circ} \mathrm{C}$ (condenser temperature variates with climatic conditions, assuming summer conditions in a country near equator line) 
5. Effectiveness of LVHE ( $\varepsilon$ or $\left.\varepsilon_{\mathrm{LVHE}}\right)=0.8$

6. Difference between evaporator temperature and space temperature $\left(\mathrm{T}_{\mathrm{b}}-\mathrm{T}_{\mathrm{e}}\right)=5^{\circ} \mathrm{C}$

7. Ambient or Dead state temperature $\left(\mathrm{T}_{0}\right)=25^{\circ} \mathrm{C}$

8. It is assumed that pressure drop in LVHE is negligible and no exeternal heat loss

9. It is assumed that the state of refrigerant is dry and saturated at the entry of compressor for LVHE vapour compression cycle (state points 1 )

10. The range of degree of subcooling $(\Delta \mathrm{T})_{\text {subcooling }}=5$ to $30^{\circ} \mathrm{C}$

11. The pressure drop in evaporator $\left(\delta_{\mathrm{e}}\right)$ and condenser $\left(\delta_{\mathrm{c}}\right)$ is assumed to be zero.

\section{Effect of subcooling $((\Delta T) s c)$}

The effect of degree of subcooling on degree of superheating, compressor work, COP and exergetic efficiency is shown in figures 3(a) to 3(c).

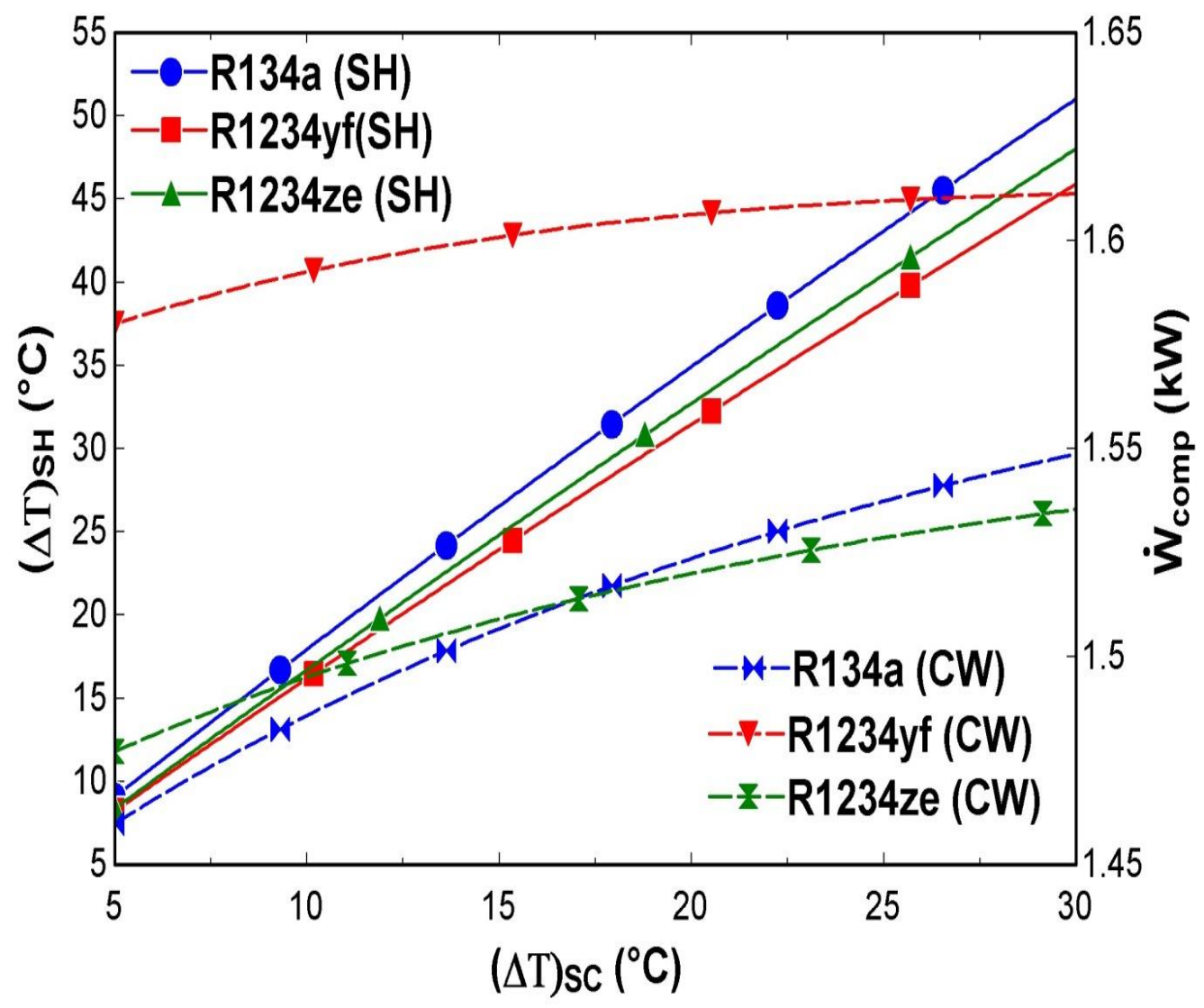

Figure 3(a). Effect of degree of subcooling $(\Delta \mathrm{T})_{\mathrm{SC}}$ on degree of superheating $(\Delta \mathrm{T})_{\mathrm{SH}}$ and compressor work $\left(\dot{W}_{\text {comp }}\right)$ for LVHE incorporated VCR cycle $\left(T_{e}=-10^{\circ} \mathrm{C}\right)$

Figure 3(a). presents the effect of mechanical subcooling on superheating and compressor work. The degree of superheating increases for considered refrigerants with the increase in degree of subcooling due to exchange of heat in the LVHE. Thus the compressor work also increases with the increase in degree of superheating. Since the specific heat of liquid refrigerant is higher than the vapour, refer to equation (5), the degree of superheating $(\Delta \mathrm{T})_{\mathrm{SH}}$ is more than the degree of subcooling $(\Delta \mathrm{T})_{\mathrm{Sc}}$. It is observed that for R134a, the superheating achieved in LVHE is higher compared to other refrigerants. Since the ratio of specific heat of liquid to specific heat of vapour is maximum in its case. The average value of $\mathrm{C}_{\mathrm{Pl}} / \mathrm{C}_{\mathrm{Pv}}$ for $\mathrm{R} 134 \mathrm{a}$ is 1.833 and the corresponding value for R1234yf and R1234ze are 1.670 and 1.739 at the temperature $50^{\circ} \mathrm{C}$ and $-10^{\circ} \mathrm{C}$ [Table 1]. 


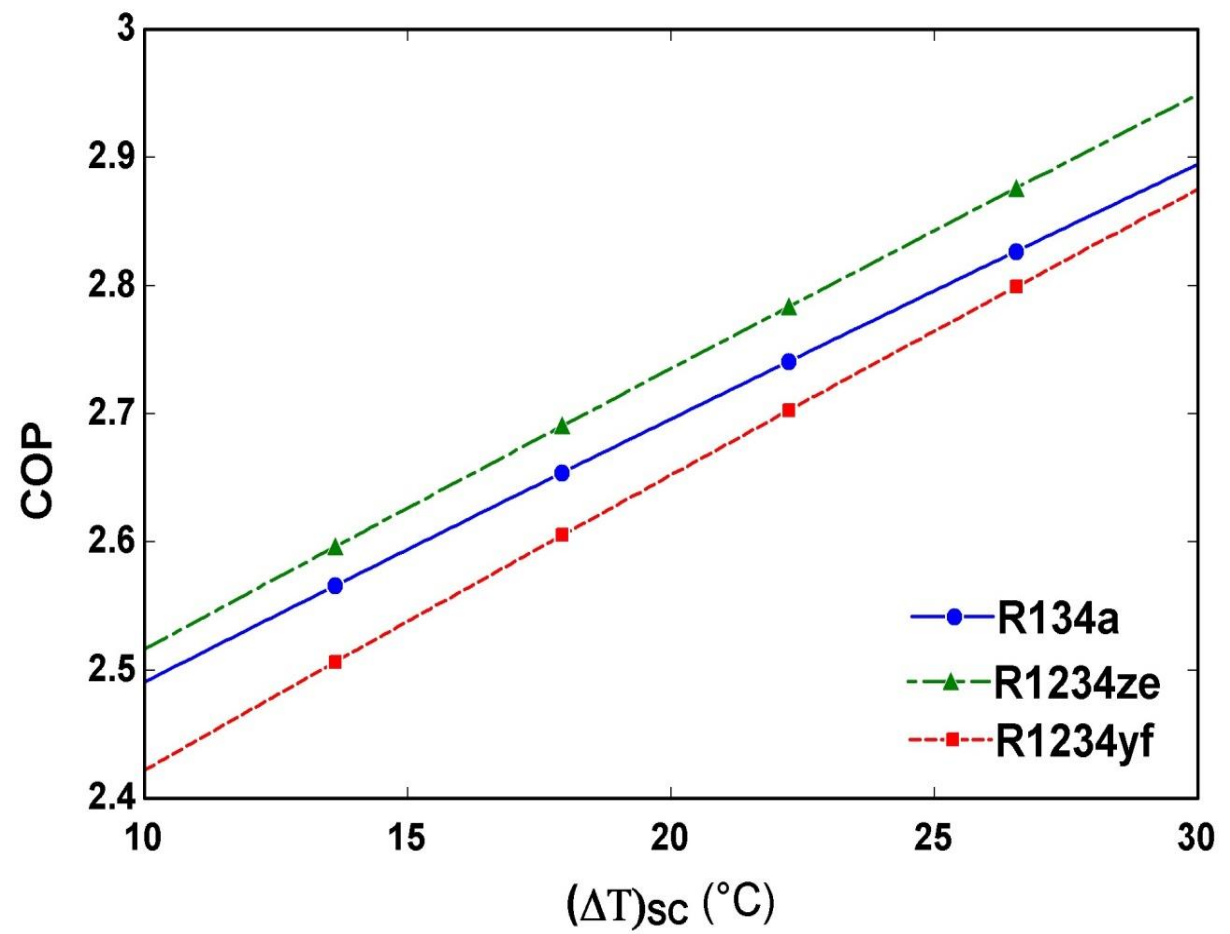

Figure 3(b). Effect of degree of subcooling $(\Delta \mathrm{T})_{\mathrm{SC}}$ on COP for LVHE incorporated VCR cycle $\left(\mathrm{T}_{\mathrm{e}}=-10^{\circ} \mathrm{C}\right)$

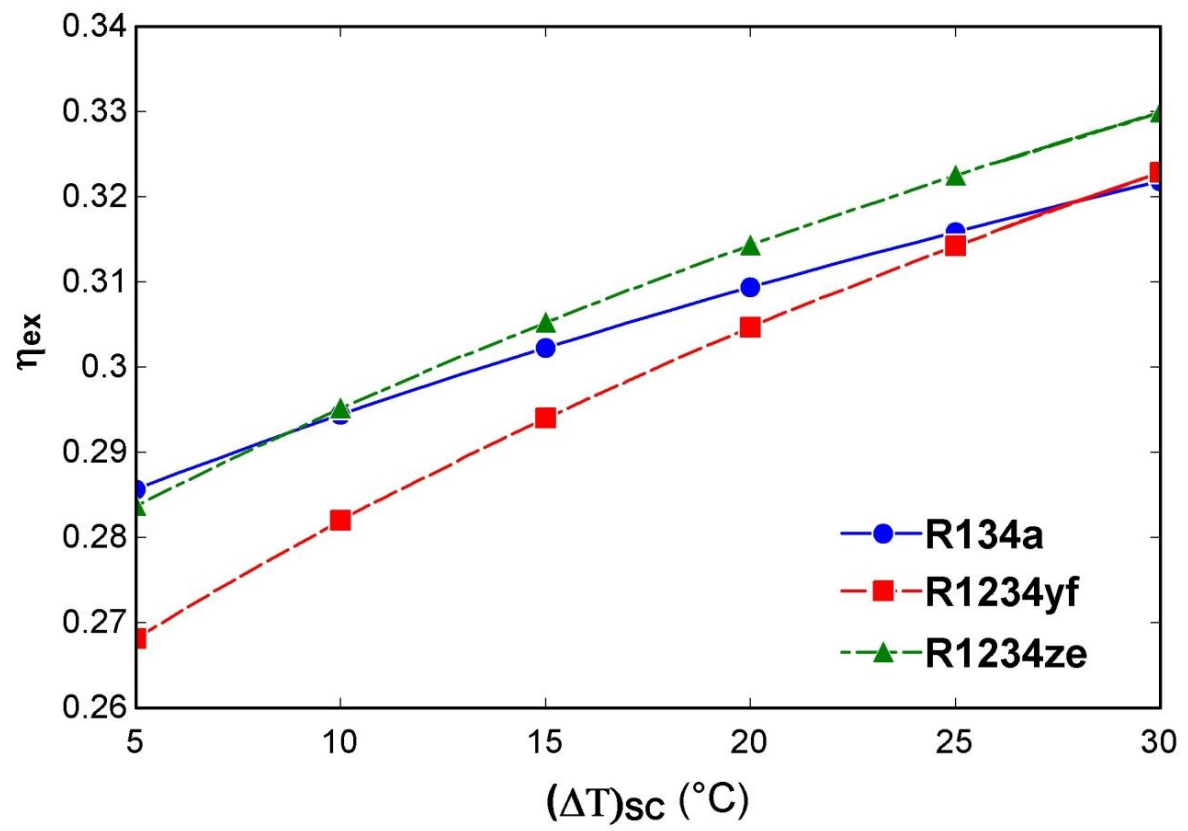

Figure 3(c). Effect of degree of subcooling $(\Delta T)_{S C}$ on exergetic efficiency $\left(\eta_{\text {ex }}\right)$ for LVHE incorporated VCR

$$
\text { cycle }\left(\mathrm{T}_{\mathrm{e}}=-10^{\circ} \mathrm{C}\right)
$$

Fig. 3(b) shows the variation of coefficient of performance (COP) with degree of subcooling for the refrigerants R134a, R1234yf and R1234ze. As the degree of subcooling increases, the compressor work also increases, however the rate of increase in specific refrigerating effect is observed to be more than the rate of increase of specific compressor work. Thus the COP of vapour compression cycle with LVHE for all the three refrigerants is observed to increase with increase in degree of subcooling. The COP of simple saturated VCR cycle (i.e. in absence of LVHE) is 2.464, 2.255 and 2.420 for R134a, R1234yf and R1234ze respectively. The refrigerant R1234ze outperforms the other two refrigerants with regard to COP. R134a shows better COP than the R1234yf for both the lower end and higher end values of subcooling. The difference in the COP for R134a and R1234ze is $1.04 \%$ at $10^{\circ} \mathrm{C}$ of subcooling while $1.87 \%$ at $30^{\circ} \mathrm{C}$ of subcooling. The percentage difference in COP for R134a 
and $\mathrm{R} 1234 \mathrm{yf}$ are $2.73 \%$ at $10^{\circ} \mathrm{C}$ and $0.69 \%$ at $30^{\circ} \mathrm{C}$ of subcooling. The difference for R1234ze and R1234yf are $3.77 \%$ at $10^{\circ} \mathrm{C}$ and $2.56 \%$ at $30^{\circ} \mathrm{C}$ of subcooling.

The effect of subcooling on exergetic efficiency is shown in Fig. 3(c). The $\eta_{\mathrm{ex}}$ is observed to increase with increase in degree of subcooling. The $\eta_{\mathrm{ex}}$ is given by the formula $\eta_{\mathrm{ex}}=\operatorname{COP} \times\left|\left(1-\frac{\mathrm{T}_{0}}{\mathrm{~T}_{\mathrm{b}}}\right)\right|$. Since the COP increases with increase in degree of subcooling whereas the term $\left|\left(1-\frac{T_{0}}{T_{b}}\right)\right|$ remains constant hence $\eta_{\text {ex }}$ increases with increase in degree of subcooling. The compressor work increases with increase in degree of subcooling, however the rate of increase in specific refrigerating effect is observed to be more than the rate of increase of compressor work. Thus the exergetic efficiency of vapour compression cycle with LVHE is observed to increase with increase in degree of subcooling for all the three refrigerants. The exergetic efficiency for simple saturated VCR cycle (i.e. in the absence of LVHE) is $0.2757,0.2523$ and 0.2707 for R134a, R1234yf and R1234ze respectively. The exergetic efficiency for R134a and R1234ze is more than the R1234yf. It is observed that the slope of curve for R134a is less than that of R1234yf and R1234ze. The percentage difference in exergetic efficiency for R1234ze and $\mathrm{R} 134 \mathrm{a}$ are $0.82 \%$ at $10^{\circ} \mathrm{C}$ and $1.88 \%$ at $30^{\circ} \mathrm{C}$ of subcooling. The difference for $\mathrm{R} 1234 \mathrm{yf}$ and $\mathrm{R} 134 \mathrm{a}$ are $3.53 \%$ at $10^{\circ} \mathrm{C}$ and $0.68 \%$ at $30^{\circ} \mathrm{C}$ of subcooling. Similarly the difference for R1234ze and $\mathrm{R} 1234 \mathrm{yf}$ are $4.38 \%$ at $10^{\circ} \mathrm{C}$ and $2.58 \%$ at $30^{\circ} \mathrm{C}$.

\section{Effect of Evaporator Temperature $\left(\mathrm{T}_{\mathrm{e}}\right)$}

The variation of evaporator temperature on various performance parameters of mechanically subcooled vapour compression cycle incorporated with LVHE is shown in Figures 4(a) to 4(d).

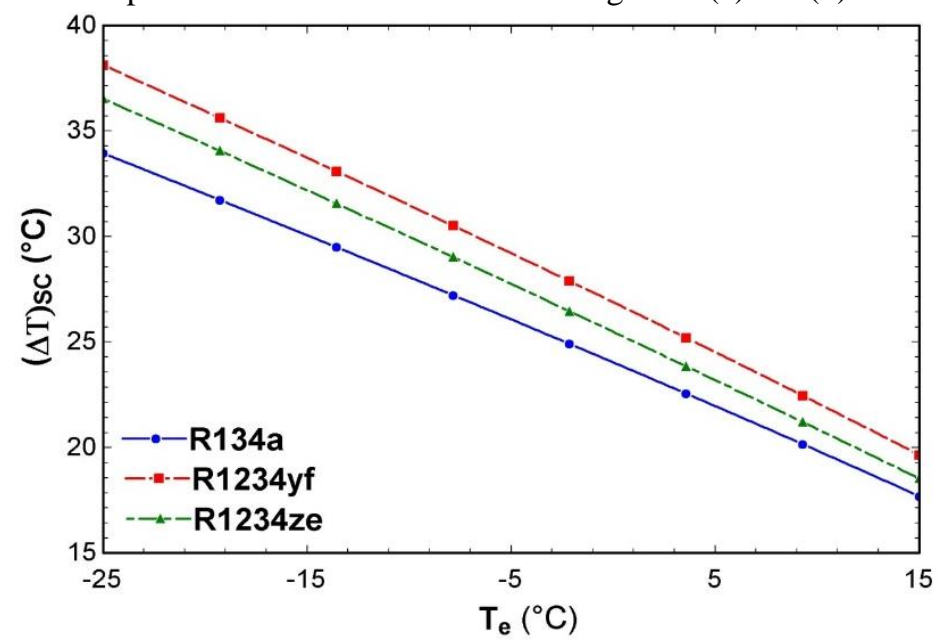

Figure 4(a). Effect of evaporator temperature $\left(T_{e}\right)$ on degree of subcooling $(\Delta T)_{S C}$ for LVHE incorporated VCR cycle

The variation of degree of subcooling with evaporator temperature is depicted in Figure 4(a). As the evaporator temperature increases, the degree of subcooling is observed to decrease. At higher evaporator temperature the rate of heat transfer form high refrigerant to low temperature refrigerant decreases and hence degree of subcooling decreases. The observed value of degree of subcooling is minimum for R134a and maximum for R1234yf.

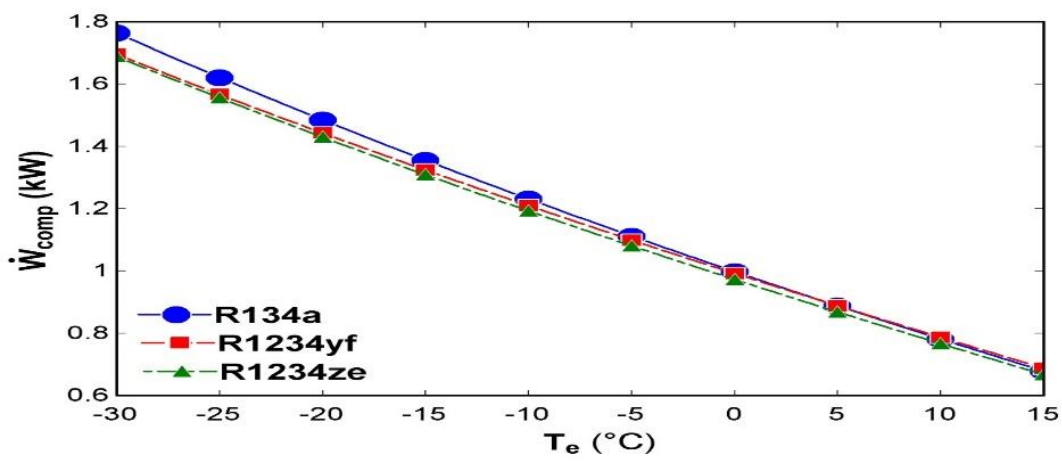

Figure 4(b). Effect of evaporator temperature $\left(T_{e}\right)$ on compressor work $\left(\dot{W}_{\text {comp }}\right)$ for LVHE incorporated VCR cycle 


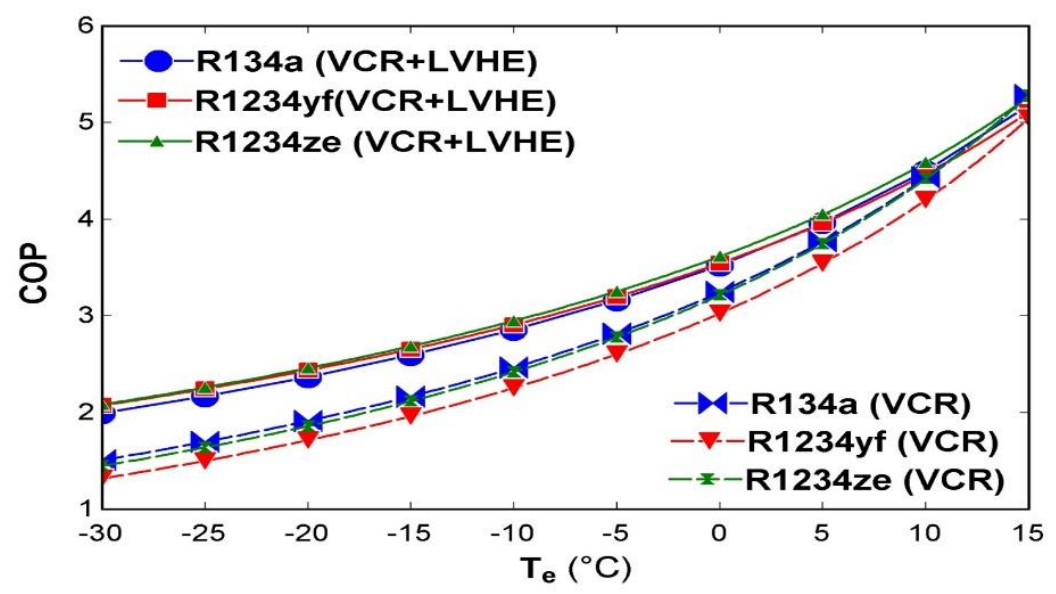

Figure 4(c). Effect of evaporator temperature $\left(\mathrm{T}_{\mathrm{e}}\right)$ on COP of VCR cycle with and without LVHE

The effect of evaporator temperatrue on compressor work is shown in Fig. 4(b). As the evaporator temeperature increases, the compressor work is observed to decrease. The pressure ratio between evaporator and compressor and degree of subcooling decrease with increase in evaporator temperature (Refer Fig. 4(a)) consequently decrease in degree of superheating. Hence the compressor work decreases. It is observed that the compressor work is least for R1234ze.

The variation of COP with evaporator temperature is shown in Fig. 4(c). The COP of VCR cycle with or without LVHE increases with increase in evaporator temperature. As the compressor work decreases with increase in evaportor temperature (Refer Fig. 4(b)) and the specific refrigerating effect increases. Thus the COP of the cycle increases. It is observed that the COP of the VCR cycle with LVHE is higher than the VCR cycle without LVHE for the considered refrigerants. At lower evaporator temperature (between $-30^{\circ} \mathrm{C}$ to $0^{\circ} \mathrm{C}$ ), the VCR cycle with LVHE performs better for the refrigerants considered.

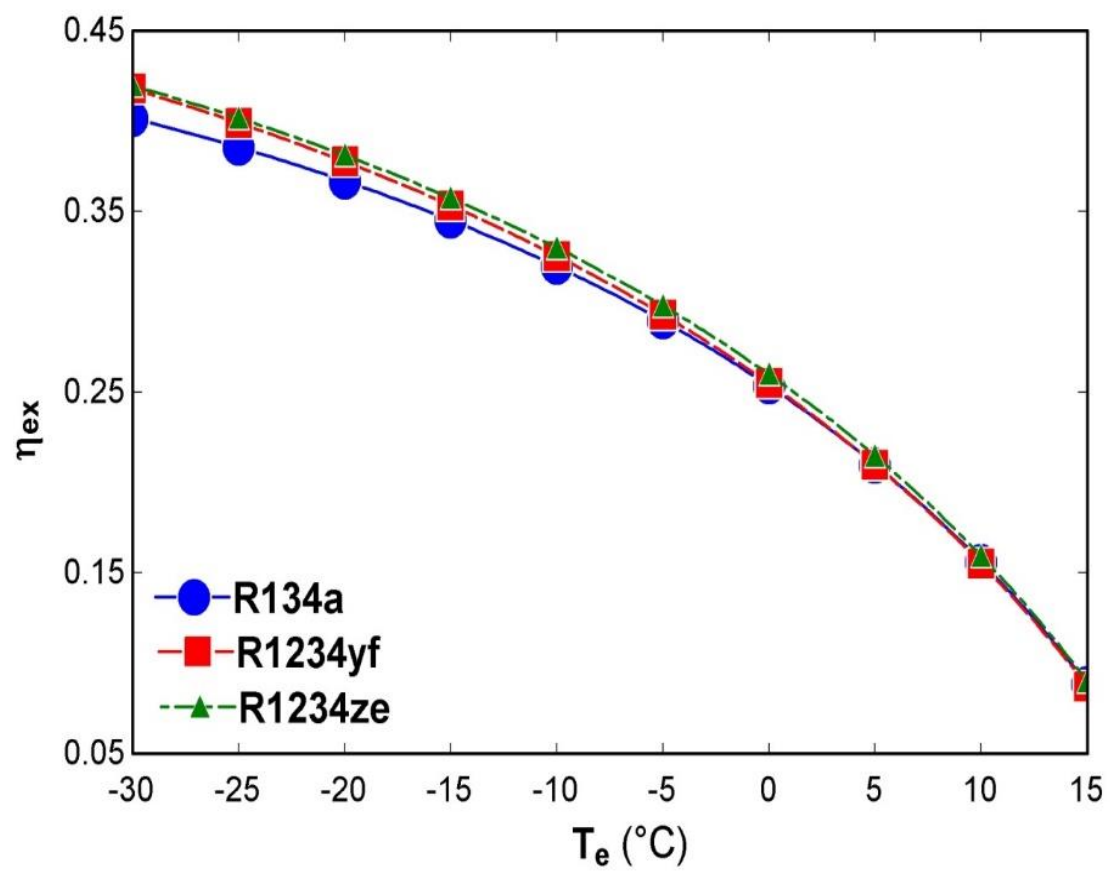

Figure 4(d). Eexergetic efficiency $\left(\eta_{\mathrm{ex}}\right)$ vs evaporator temperature $\left(T_{\mathrm{e}}\right)$ for LVHE incorporated VCR cycle

The variation of exergetic efficiency with evaporator temperature is shown in Fig. 4(d). The exergetic efficiency decreases with increase in evaporator temperature. Exergetic efficiency is given by formula 
$\eta_{e x}=\operatorname{COP} \times\left|\left(1-\frac{T_{0}}{T_{b}}\right)\right|$, the term COP increases (Refer Fig. 4(c)) on the other hand, the term $\left|\left(1-\frac{T_{0}}{T_{b}}\right)\right|$ decreases with increase in evaporator temperature (i.e. $\left(\mathrm{T}_{\mathrm{b}}-\mathrm{T}_{\mathrm{e}}\right)=5^{\circ} \mathrm{C}$ ). Thus the result of two is that the exergetic efficiency decreases. It is observed that the exergetic efficiency is least for R134a and highest for R1234ze.

\section{Effect of Effectiveness of Liquid Vapour Heat Exchanger $\left(\varepsilon_{\mathrm{LVHE}}\right)$}

The variation of effectiveness of liquid vapour heat exchanger on various performance parameters is shown in figures $5(\mathrm{a})$ to $5(\mathrm{~d})$.

Fig. 5(a) shows the effect of effectiveness of LVHE on degree of subcooling. As the effectiveness of LVHE increases, the degree of subcooling of the LVHE cycle increases due to increasing rate of heat extraction from the liquid refrigerant.

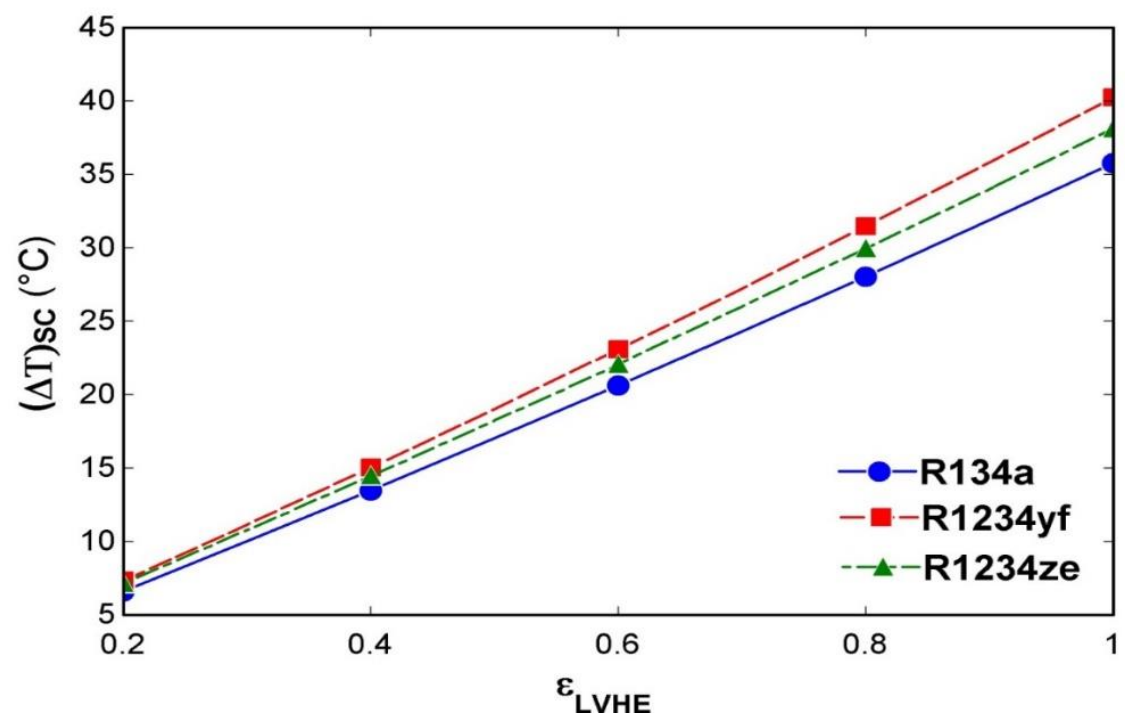

Figure 5(a). Degree of subcooling $(\Delta \mathrm{T})_{\mathrm{SC}}$ vs effectiveness of liquid vapour heat exchanger $\left(\varepsilon_{\mathrm{LVHE}}\right)\left(\mathrm{T}_{\mathrm{e}}=-10^{\circ} \mathrm{C}\right)$

It is observed that R1234yf registers more increase in degree of subcooling in comparison to R134a and R1234ze.

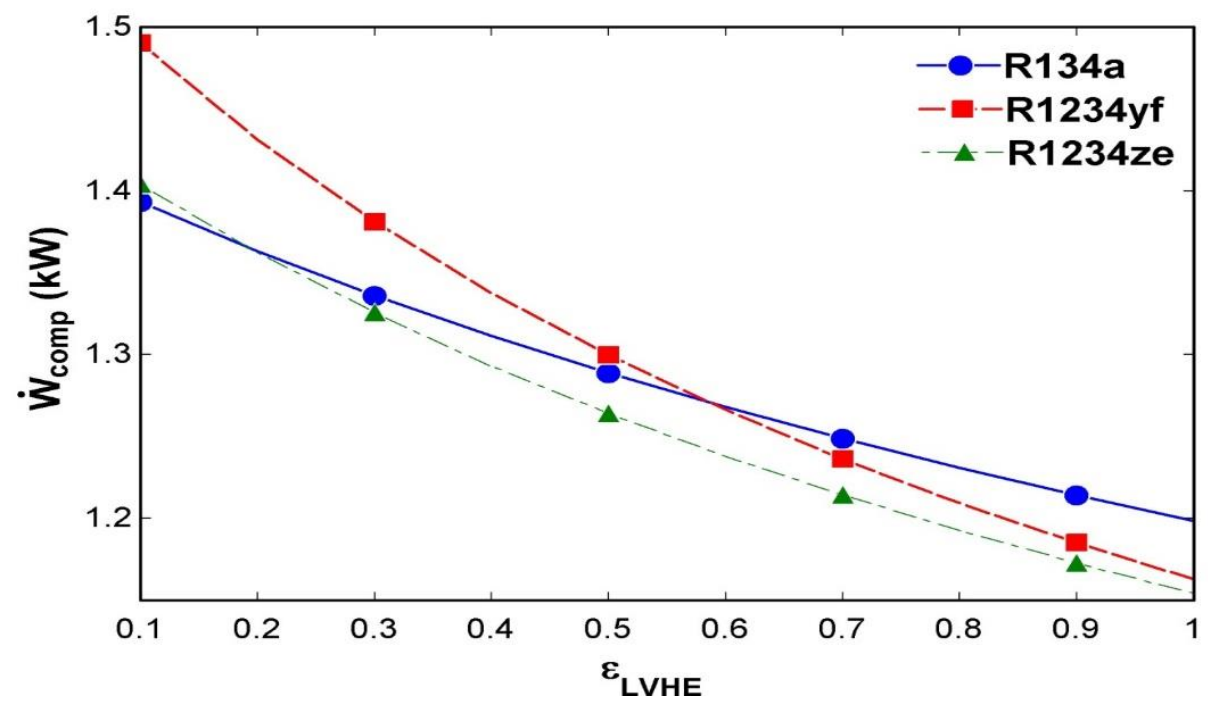

Figure 5(b). Compressor work $\left(\dot{\mathrm{W}}_{\text {comp }}\right)$ vs effectiveness of liquid vapour heat exchanger $\left(\varepsilon_{\mathrm{LVHE}}\right)\left(\mathrm{T}_{\mathrm{e}}=-10^{\circ} \mathrm{C}\right)$

Fig. 5(b) shows the effect of effectiveness of LVHE on compressor work. The compressor work decreases with increase in effectiveness of liquid vapour heat exchanger. For the considered operating conditions with 
increase in effectiveness of LVHE, the mass flow rate of the refrigerant decreases and hence the compressor work also decreases.It is observed that the compressor work decreases more for refrigerant R1234yf than the other two refrigerants. For R134a the decrease in compressor work is least.

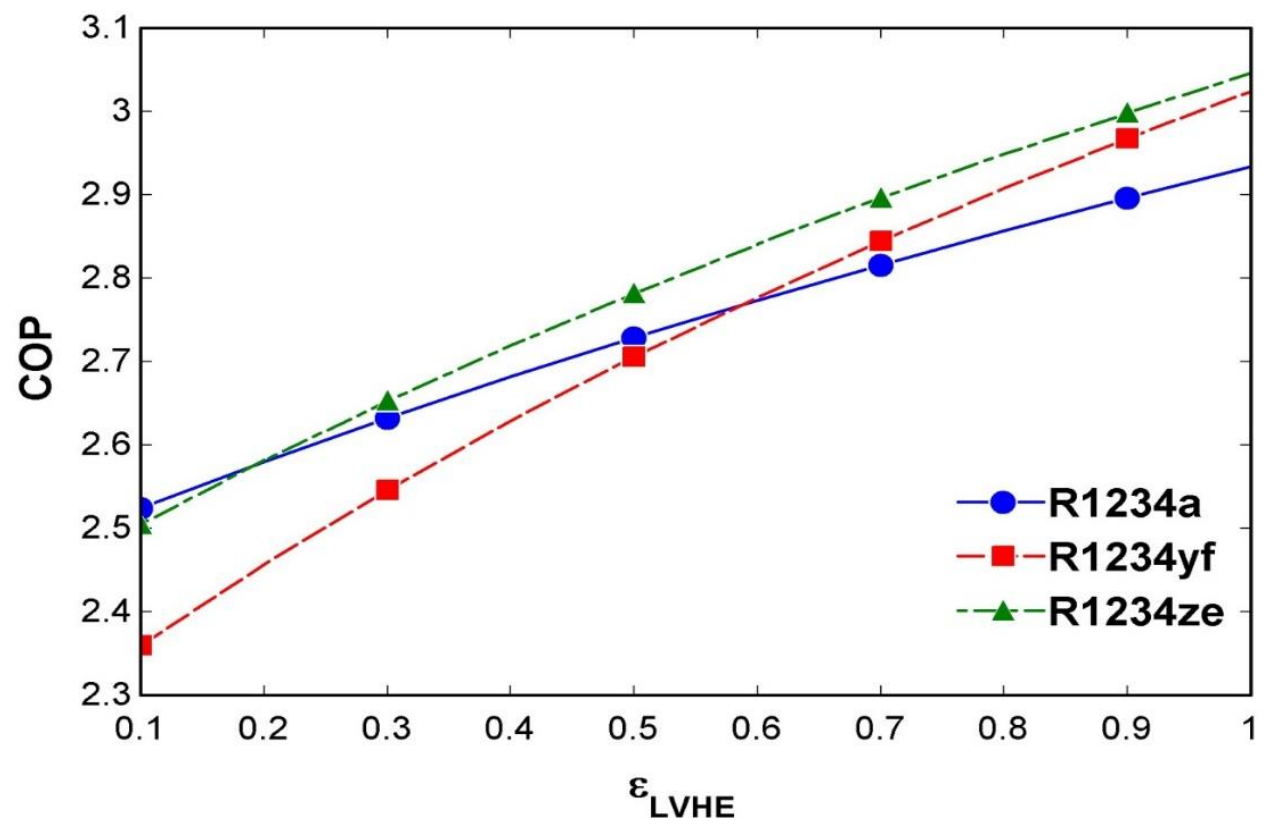

Figure 5(c). Coefficient of performance (COP) vs effectiveness of liquid vapour heat exchanger $\left(\varepsilon_{\mathrm{LVHE}}\right)\left(\mathrm{T}_{\mathrm{e}}=-10^{\circ} \mathrm{C}\right)$

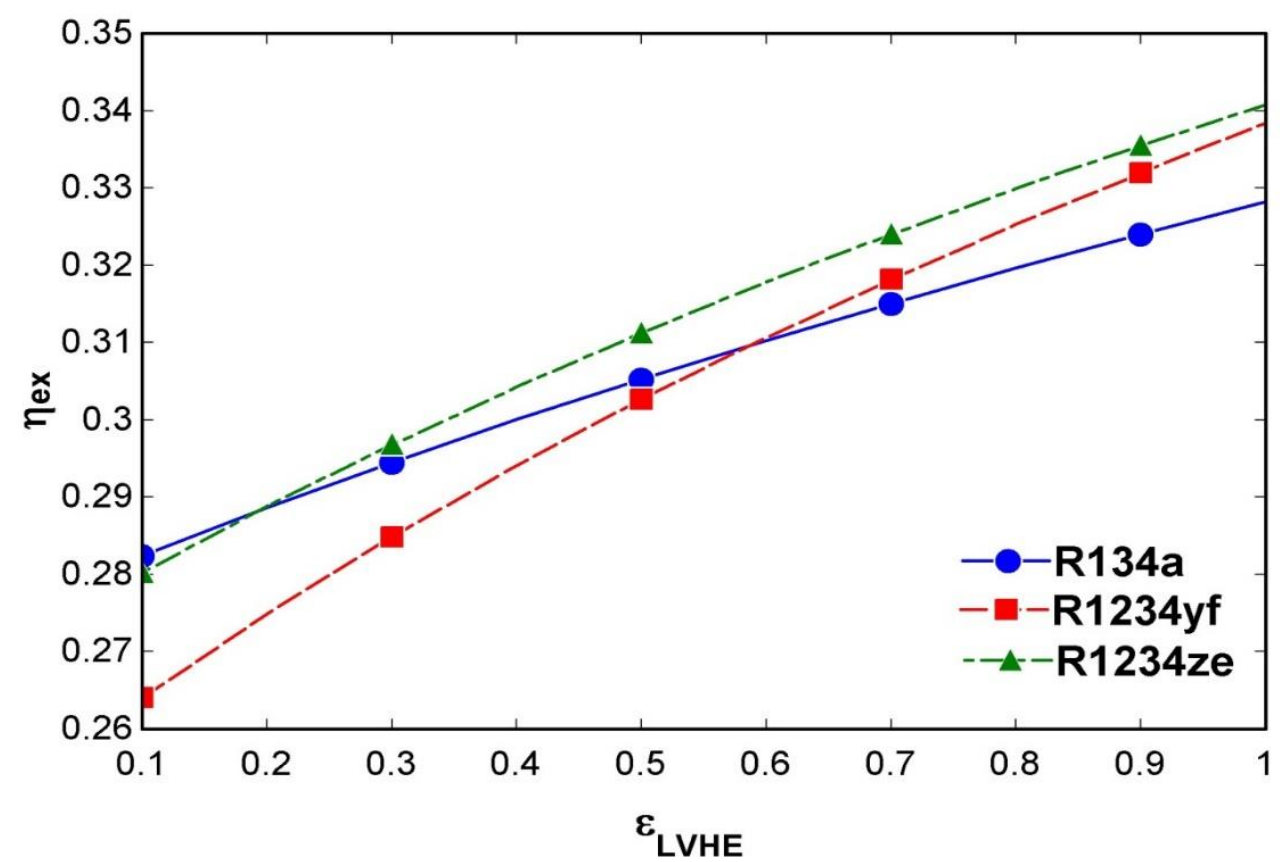

Figure 5(d). Exergetic efficiency $\left(\eta_{\mathrm{ex}}\right)$ vs effectiveness of liquid vapour heat exchanger $\left(\varepsilon_{\mathrm{LVHE}}\right)\left(\mathrm{T}_{\mathrm{e}}=-10^{\circ} \mathrm{C}\right)$

Fig. 5(c) shows the variation of COP with effectiveness of LVHE. The COP of the cycle increases with icrease in values of effectiveness of liquid vapour heat exchanger. Figs. 5(a) and 5(b) show that the degree of subcooling increases and refrigeranting effect increases while the compressor work decreases with increase in values of LVHE effectiveness. Hence the COP of the cycle increases. It is observed that the rate of increase in $\mathrm{COP}$ of the cycle for refrigerant R1234yf is more than the other two refrigerants. The increase in COP is least for R134a. 
Fig. 5(d) shows the effect of effectiveness of LVHE on the exergetic efficiency. The exergetic efficiency of the cycle increases with increase in effectiveness of LVHE. Due to increase in refrigerating effect and decrease in compressor work (refer Figs. 5(a) and 5(b)), the exergetic efficiency increases. It is observed that the increase in exergetic efficiency is maximum for R1234yf and is minimum for refrigerant R134a.

\section{Effect of Compressor Efficiency ( $\eta_{\text {comp }}$ )}

The variation of compressor efficiency on different performance parameter is shown in figures 6 (a) and 6(b).

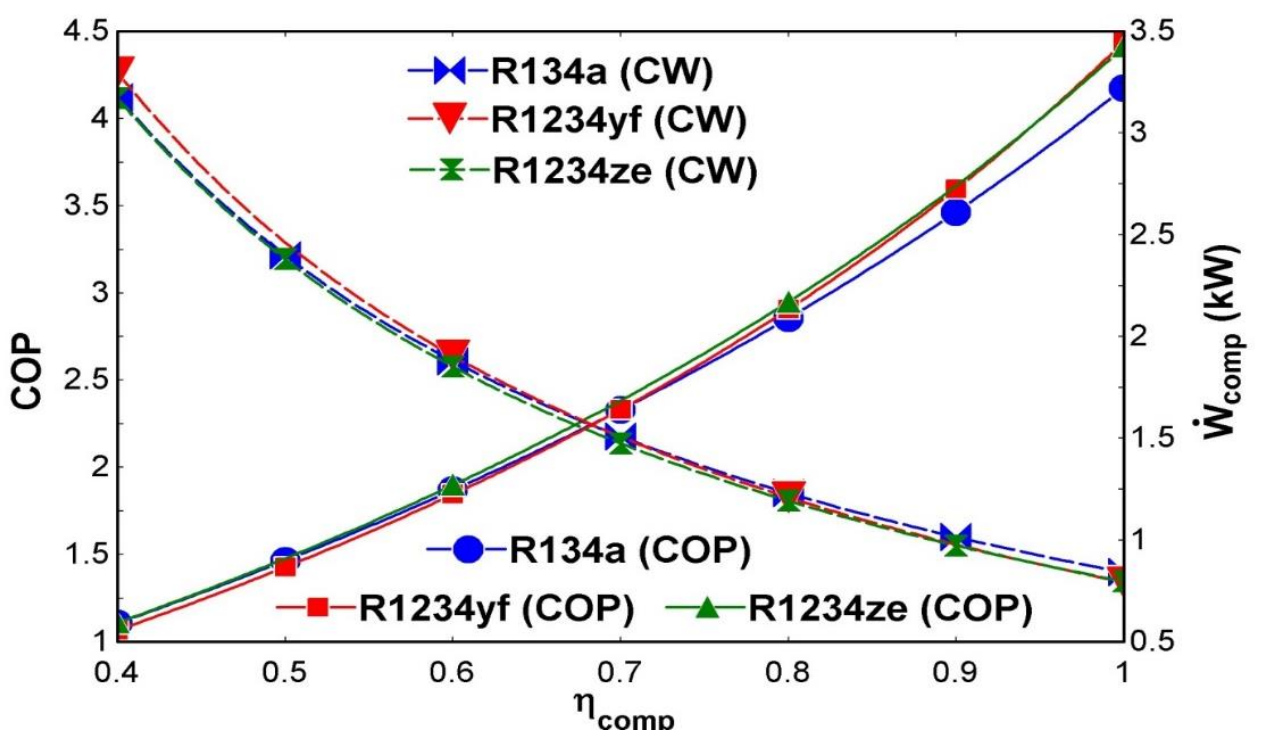

Figure 6(a). Coefficient of performance (COP) and compressor work $\left(\dot{\mathrm{W}}_{\text {comp }}\right)$ vs isentropic compressor efficiency $\left(\eta_{\text {comp }}\right)\left(\mathrm{T}_{\mathrm{e}}=-10^{\circ} \mathrm{C}\right)$

Fig. 6(a) shows the effect of isentropic efficiency of compressor on COP of the cycle and compressor work. It is observed that the COP of the cycle increases with increase in isentropic efficiency of compressor for the refrigerants considered. The reason for increase in COP of the cycle is reduction in compressor work with increase in isentropic $\boldsymbol{\eta}$ of compressor It is observed that the increment in the COP is maximum for refrigerant R1234yf and minimum for R134a while the decrease in compressor work is maxmimum for R1234yf and minimum for R134a.

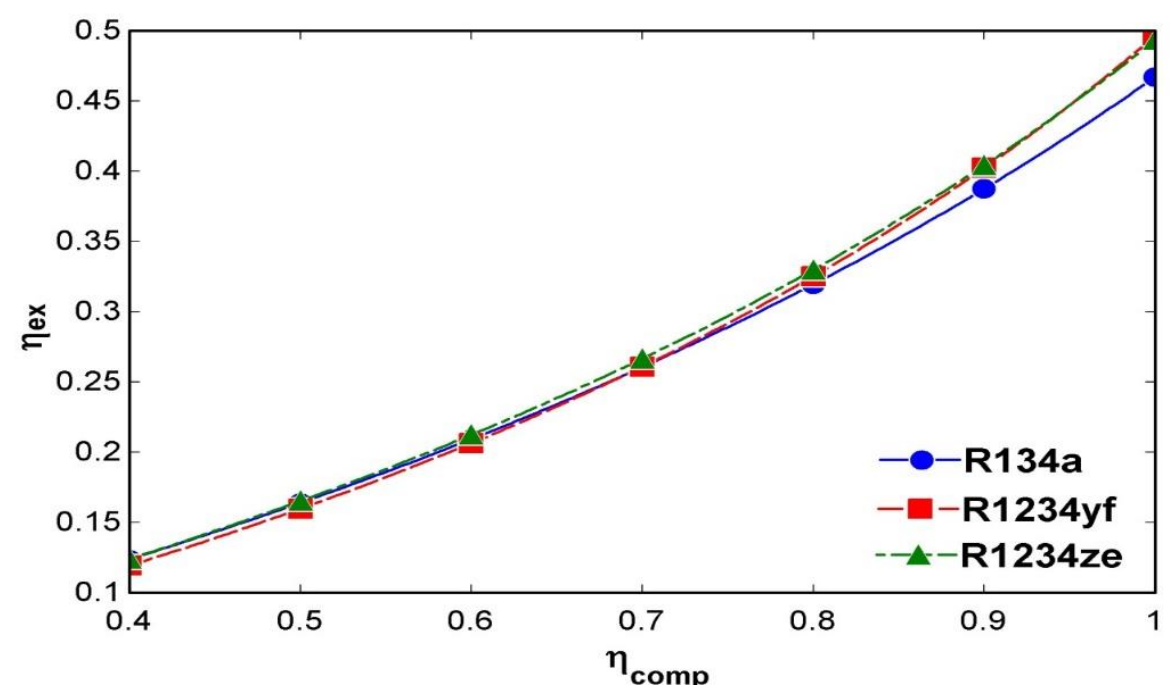

Figure 6(b). Exergetic efficiency $\left(\eta_{\mathrm{ex}}\right)$ vs isentropic compressor efficiency $\left(\eta_{\text {comp }}\right)\left(\mathrm{T}_{\mathrm{e}}=-10^{\circ} \mathrm{C}\right)$

Fig. 6(b) shows the effect of isentropic efficiency of compressor on the exergetic efficiency of the cycle. The exergetic efficiency of the cycle increases with increase in compressor efficiency for the considred 
refrigerants. As the compressor work decreases (Refer Fig. 6(a)), the exergetic efficiency of the cycle increases. It is observed that the increment in the exergetic efficiency is maximum for refrigerant R1234ze and minimum for refrigerant R134a.

Effect of Subcooling $(\Delta T)_{s c}$, Evaporator Temperature $\left(T_{e}\right)$, Effectiveness of LVHE $\left(\varepsilon_{L V H E}\right)$ and Compressor Efficiency ( $\eta_{\text {comp }}$ ) on Total Exergy Destruction and Exergy Destruction Ratio (EDR)

The effect of subcooling $(\Delta \mathrm{T})_{\mathrm{SC}}$, evaporator temperature $\left(\mathrm{T}_{\mathrm{e}}\right)$, effectiveness of LVHE $\left(\varepsilon_{\mathrm{LVHE}}\right)$ and compressor efficiency ( $\eta_{\text {comp }}$ ) on performance parameters viz. total exergy destruction and exergy destruction ratio is shown in figure 7.
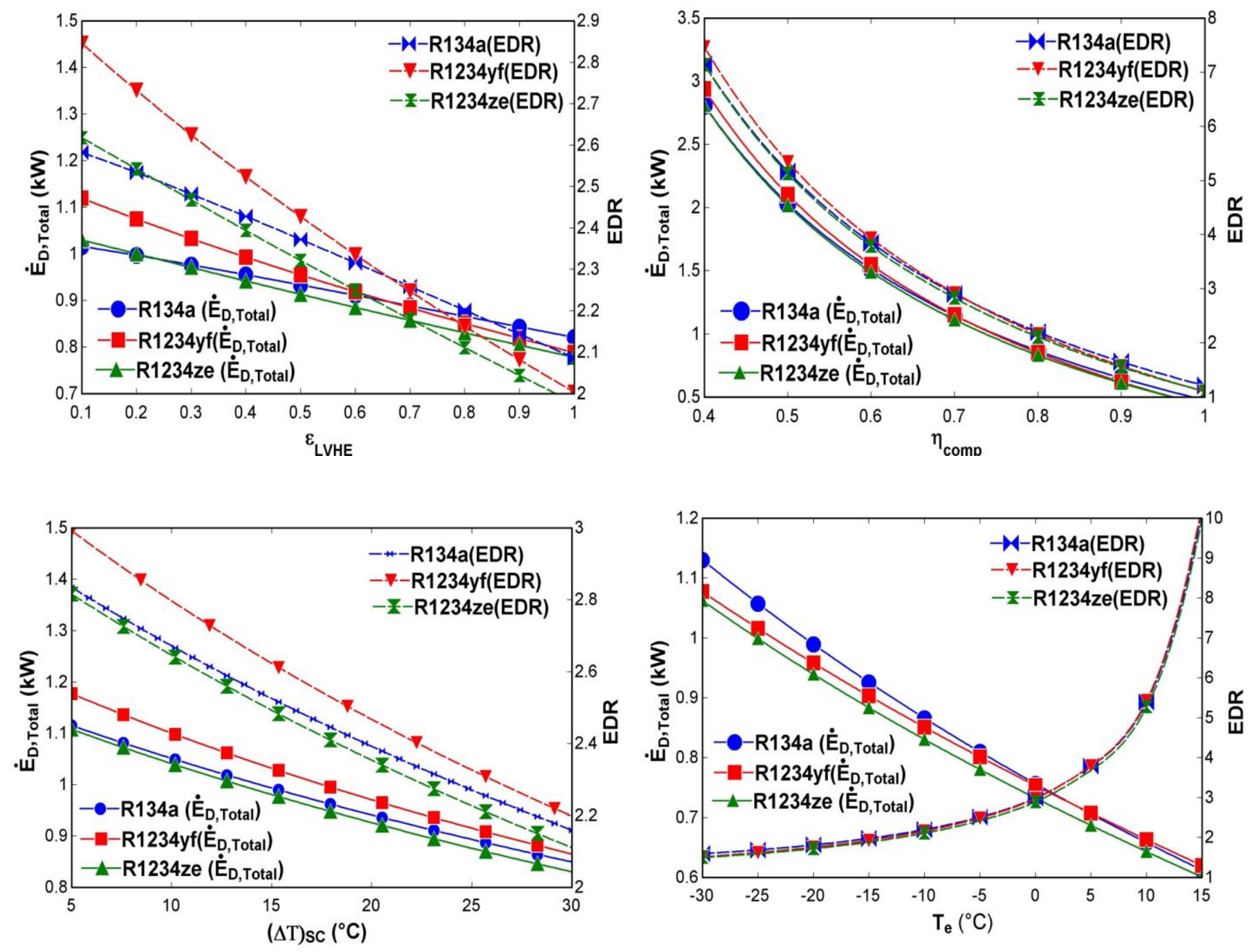

Figure 7. The total exergy destruction and exergy destruction ratio vs. degree of subcooling $(\Delta \mathrm{T})_{\mathrm{Sc}}$, evaporator temperature $\left(T_{e}\right)$, effectiveness of LVHE ( $\left.\varepsilon_{\text {LVHE }}\right)$ and isentropic efficiency of compressor $\left(\eta_{\text {comp }}\right)$

The total exergy destruction and exergy destruction ratio decrease with increase in degree of subcooling, effectiveness of LVHE and isentropic efficiency of compressor. However total exergy destruction increases and exergy destruction ratio decreases with increase in evaporator temperature. Refer to the Figs. 3(c), 5(d) and 6(b), the exergetic efficiency increases with increase in degree of subcooling, effectiveness of LVHE and isentropic efficiency of compressor consequently total exergy destruction and exergy destruction ratio decrease. The exergetic efficiency decrease with increase in evaporator temperature (refer Fig. 4(d)) results decrease in total exergy destruction and exergy destruction ratio. It is observed that the R1234ze reaches its minimum value while the R1234yf and R134a fluctuate for maximum value. 

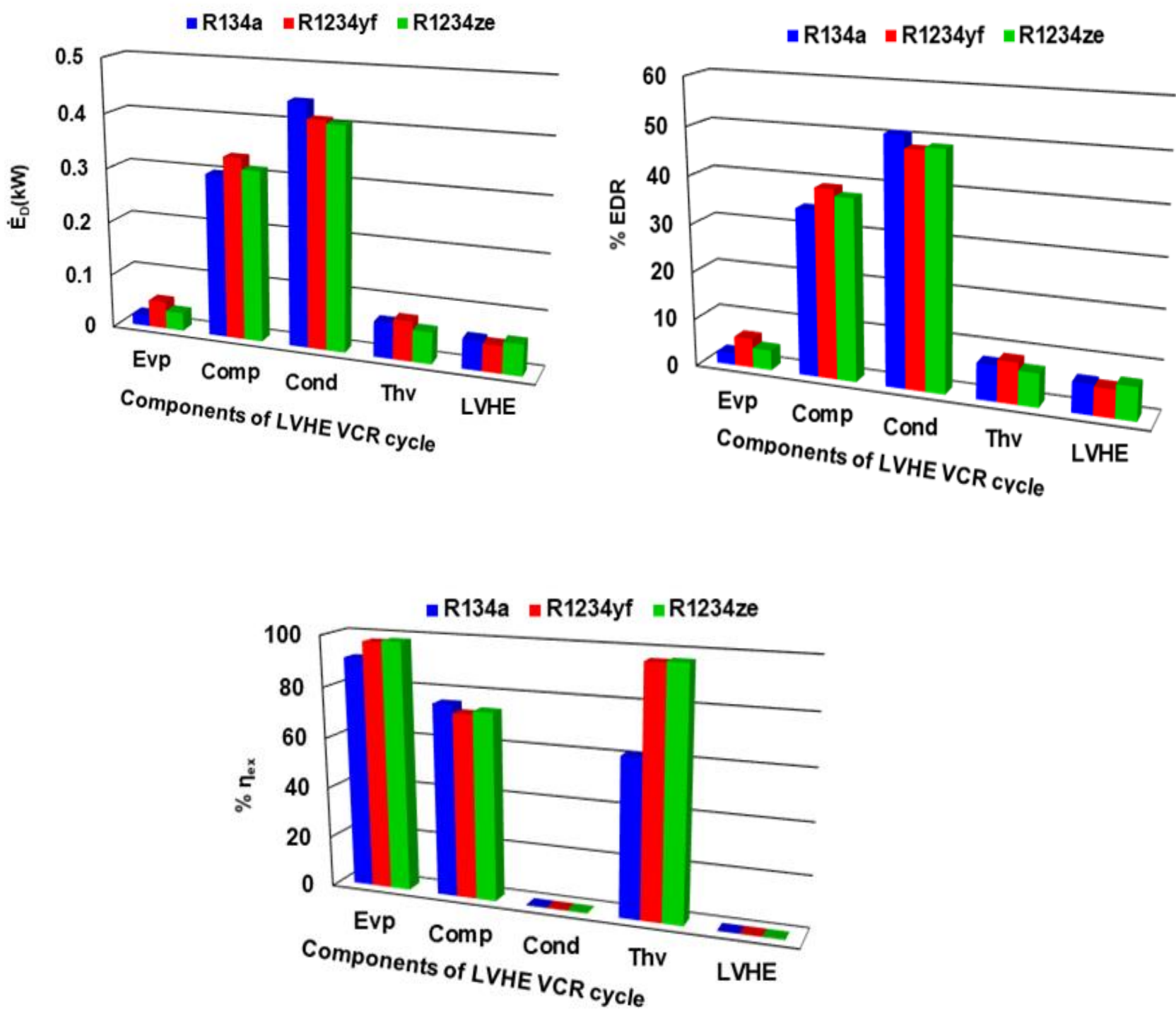

Figure 8. Exergy destruction $\left(\dot{\mathrm{E}}_{\mathrm{D}}\right)$, percentage of exergy destruction ratio (\%EDR) and percentage of exergetic efficiency $\left(\eta_{e x}\right)$ in different components of LVHE associated VCR system $\left(T_{e}=-10^{\circ} \mathrm{C}\right)$

The variation of exergy destruction, \% EDR and \% exergetic efficiency in different components of VCR system incorporated LVHE is shown in Fig. 8 for the considered refrigerants. The exergy destruction and \% EDR are highest in condenser and lowest in evaporator as compared to other system components viz. compressor, throttle valve and LVHE. Hence the system components condenser and evaporator are the sites of highest and lowest exergy destruction. On the other hand the system component evaporator is the site of highest exergy recovery as the exergetic efficiency of evaporator is observed to be highest. The exergetic efficiency of condenser and LVHE is observed to be zero. Thus the system components condenser and LVHE are the sites of lowest exergy recovery. However exergetic efficiency of throttle valve and compressor is observed higher than that of condenser and LVHE and lower than evaporator for the considered refrigerants. It is observed that the value of exergy destruction and \% of EDR are lowest for R134a in the evaporator and highest for R134a in the condenser. The exergetic efficiency is highest for R1234ze in the evaporator. The exergy recovery in the throttle valve and compressor is carried out by R1234ze higher than the other refrigerants. 
Table 2. The results of exergy analysis of VCR cycle equipped with LVHE $\left(\mathrm{T}_{\mathrm{e}}=-10^{\circ} \mathrm{C},(\Delta \mathrm{T})_{\mathrm{SC}}=5^{\circ} \mathrm{C}\right)$

\begin{tabular}{|c|c|c|c|c|c|c|}
\hline \multirow[t]{2}{*}{ Refrigerants } & \multicolumn{6}{|c|}{ System components of LVHE VCR cycle } \\
\hline & & Evp & Comp & Cond & Thv & LVHE \\
\hline \multirow{5}{*}{$\begin{array}{l}\text { R134a } \\
\text { (HFC) }\end{array}$} & $\dot{\mathbf{E}}_{\text {in }}(\mathbf{k W})$ & -0.6257 & -0.6334 & 0.2976 & -0.1679 & -0.7473 \\
\hline & $\dot{\mathbf{E}}_{\text {out }}(\mathbf{k W})$ & -0.6048 & 0.2976 & -0.1425 & -0.2323 & -0.8013 \\
\hline & $\dot{\mathrm{E}}_{D}(\mathbf{k W})$ & 0.0772 & 0.3000 & 0.4401 & 0.0644 & 0.0540 \\
\hline & $E D R$ & 0.0089 & 0.3463 & 0.5081 & 0.0743 & 0.0624 \\
\hline & $\eta_{\mathrm{ex}}$ & 0.9100 & 0.7563 & 0 & 0.6168 & 0 \\
\hline \multirow{5}{*}{$\begin{array}{l}\text { R1234yf } \\
\text { (HFO) }\end{array}$} & $\dot{\mathbf{E}}_{i n}(\mathbf{k W})$ & 2.4400 & -0.2424 & -1.5480 & -1.9730 & -4.3490 \\
\hline & $\dot{\mathbf{E}}_{\text {out }}(\mathbf{k W})$ & -2.3890 & -1.5480 & -1.9590 & -2.4060 & -4.3980 \\
\hline & $\dot{\mathrm{E}}_{D}(\mathbf{k W})$ & -0.0154 & 0.3335 & 0.4109 & 0.0729 & 0.0491 \\
\hline & $E D R$ & -0.0181 & 0.3919 & 0.4828 & 0.0857 & 0.0577 \\
\hline & $\eta_{\mathrm{ex}}$ & 0.9754 & 0.7243 & 0 & 0.9631 & 0 \\
\hline \multirow{5}{*}{$\begin{array}{l}\text { R1234ze } \\
\text { (HFO) }\end{array}$} & $\dot{\mathbf{E}}_{i n}(\mathbf{k W})$ & -2.2550 & -2.2530 & -1.3740 & -1.8040 & -4.0010 \\
\hline & $\dot{\mathbf{E}}_{\text {out }}(\mathbf{k W})$ & -2.2222 & -1.3740 & -1.7790 & -1.8620 & -4.0580 \\
\hline & $\dot{\mathbf{E}}_{D}(\mathbf{k W})$ & -0.0019 & 0.3130 & 0.4051 & 0.0576 & 0.0569 \\
\hline & $E D R$ & -0.0023 & 0.3768 & 0.4876 & 0.0693 & 0.0686 \\
\hline & $\eta_{\text {ex }}$ & 0.9820 & 0.7375 & 0 & 0.9681 & 0 \\
\hline
\end{tabular}

\section{CONCLUSIONS}

The present work compared the low GWP refrigerants R1234yf and R1234ze to R134a in a vapour compression refrigeration cycle mechanically subcooled by a liquid vapour heat exchanger (LVHE). The energy and exergy analysis have been carried out for a theoretical model of LVHE incorporated to VCR cycle using R134a, R1234yf and R1234ze. The effect of degree of subcooling, evaporator temperature, effectiveness of LVHE and isentropic efficiency of compressor have been observed on compressor work, degree of superheating, COP, exergetic efficiency, total exergy destruction and exergy destruction ratio of the system. The exergetic efficiency, exerg destruction and exergy destruction ratio of system components have also been evaluated. The results have been compared for simple VCR and VCR cycle subcooled by an incorporated LVHE and are presented for three different refrigerants R134a, R1234yf and R1234ze. The conclusions of the present communication are summarised below:

- The COP of the cycle is higher for HFO-R1234ze than R134a and R1234yf. The COP of the cycle enhances with the increase in different variables i.e. degree of subcooling, evaporator temperature, effectiveness of LVHE and isentropic efficiency of compressor. Similarly the cycle achieves highest value of exegetic efficiency for R1234ze.

- The values of performance parameters are lower for R1234yf than the HFC-R134a. However the difference is comparable small and it has eco-loving characteristics, so it can be a considerable replacement of $\mathrm{R} 134 \mathrm{a}$.

- The greater amount of exergy destruction takes place with the R1234yf and R134a.

- The condenser is the site of major portion of exergy destruction.

- The exergy destruction in the evaporator takes place lower than the other components.

- The highest exergetic efficiency is obtained by the evaporator.

- The exergetic efficiencies of condenser and LVHE are lower as compared to other system components.

In the light of above conclusions, it is inferred that HFO-R1234ze is the best among the refrigerants considered and can replace the traditional HFC-R134a with minor modifications in design. Although the performance of HFO-R1234yf is lower than that of HFC-R134a, having eco-loving characteristics and small deviation in the values of performance parameters, it can be a good alternative to HFC-134a. It is also predicted that the condenser and evaporator are most sensitive system components in context to the recovery of exergy criteria. 


\section{NOMENCLATURE}

COP Coefficient of performance

ED Exergy destruction

$\dot{\mathrm{E}}_{\mathrm{D}} \quad$ Exergy destruction rate $(\mathrm{kW})$

EDR Exergy destruction ratio

EES Engineering equation solver

GWP Global warming potential

$\mathrm{H}$ Specific enthalpy $(\mathrm{kJ} / \mathrm{kg})$

HFC Hydrofluorocarbon

HFO Hydrofluoroolefin

LVHE Liquid vapour heat exchanger

$\dot{\mathrm{m}}_{\mathrm{r}} \quad$ Mass flow rate of refrigerant $(\mathrm{kg} / \mathrm{s})$

ODP Ozone depleting potential

$\mathrm{P} \quad$ Pressure $(\mathrm{kPa})$

$\dot{Q} \quad$ Rate of net refrigerating effect $(\mathrm{kW})$

s Specific entropy $\left(\mathrm{kJ} / \mathrm{kg}^{\circ} \mathrm{C}\right)$

$\mathrm{T} \quad$ Temperature $\left({ }^{\circ} \mathrm{C}\right)$

$\mathrm{T}_{0} \quad$ Dead state temperature $\left({ }^{\circ} \mathrm{C}\right)$

$\mathrm{T}_{\mathrm{b}} \quad$ Boundary temperature $\left({ }^{\circ} \mathrm{C}\right)$

$\mathrm{T}_{\mathrm{e}} \quad$ Evaporator temperature $\left({ }^{\circ} \mathrm{C}\right)$

VCR Vapour compression refrigeration

$\dot{W} \quad$ Work rate $(\mathrm{kW})$

Greek symbols

$(\Delta \mathrm{T})_{\mathrm{SC}}$ Degree of subcooling $\left({ }^{\circ} \mathrm{C}\right)$

$(\Delta \mathrm{T})_{\mathrm{SH}} \quad$ Degree of superheating $\left({ }^{\circ} \mathrm{C}\right)$

$\varepsilon \quad$ Effectiveness

$\eta \quad$ Efficiency

$\delta_{\mathrm{c}} \quad$ Pressure drop in condenser $(\mathrm{kPa})$

$\delta_{\mathrm{e}} \quad$ Pressure drop in evaporator $(\mathrm{kPa})$

Subscripts

$0 \quad$ Dead state

b Boundary

comp Compressor

CW Compressor work

Cond Condense

$\mathrm{C}_{\mathrm{pl}} \quad$ Specific heat of liquid refrigerant $\left(\mathrm{kJ} / \mathrm{kg}^{\circ} \mathrm{C}\right)$

$\mathrm{C}_{\mathrm{pv}} \quad$ Specific heat of vapour refrigerant $\left(\mathrm{kJ} / \mathrm{kg}^{\circ} \mathrm{C}\right)$

D Destruction

evp Evaporator

ex Exergetic

$\mathrm{h}_{\mathrm{fg}} \quad$ Heat of vaporization $(\mathrm{kJ} / \mathrm{kg})$

$\mathrm{r} \quad$ Refrigerant

SC Subcooling

SH Superheating

thv Throttle valve

\section{REFERENCES}

[1] Ahmadi P, Dincer I, Rosen MA. Thermodynamic modeling and multi-objective evolutionary-based optimization of a new multigeneration energy system. Energy Conversion and Management. 2013 Dec 1;76: 282-300. https://doi.org/10.1016/j.enconman.2013.07.049

[2] Ansari NA, Yadav B, Kumar J. Theoretical exergy analysis of HFO-1234yf and HFO-1234ze as an alternative replacement of HFC-134a in simple vapour compression refrigeration system. International Journal of Scientific \& Engineering Research. 2013 Aug; 4(8):137.https://doi.org/ 10.21275/v5i4.nov162977 
[3] Arora A, Arora BB, Pathak BD, Sachdev HL. Exergy analysis of a vapour compression refrigeration system with R-22, R-407C and R-410A. International journal of Exergy. 2007 Jan 1;4(4):441-54. https://doi.org/10.1504/IJEX.2007.015083

[4] Arora A, Dixit M, Kaushik SC. Computation of optimum parameters of a half effect water lithium bromide vapour absorption refrigeration system. Journal of Thermal Engineering. 2016 Apr 1;2 (2):683-92. https://doi.org/10.18186/jte.19785

[5] Arora A, Dixit M, Kaushik SC. Energy and exergy analysis of a double effect parallel flow LiBr/H2O absorption refrigeration system. Journal of Thermal Engineering. 2016 Jan 1;2 (1):541-9. https://doi.org/10.18186/jte.63682

[6] Arora A, Kaushik SC. Theoretical analysis of a vapour compression refrigeration system with R502, R404A and R507A. International journal of refrigeration. 2008 Sep 1;31 (6):998-1005.

[7] Standard AS. Designation and safety classification of refrigerants. Ansi/Ashrae Standard. 2010:34-2007.

[8] Azzouzi D, Kelkouli M, Amaryoucef F. Parametric study of the wire-on-tube condenser subcooling effect on the performance of vapor compression refrigeration system. Applied Thermal Engineering. 2017 Jul 25;122: 528-34. https://doi.org/10.1016/j.applthermaleng.2017.05.003

[9] Bejan AB. A., Tsatsaronis, G., Moran, M. Thermal Design \& Optimization. 1996.

[10] Bitzer Refrigerant Report 18: BITZER Khulmaschinenbau GmbH EschenbrunntestraBe 15//71065 Sindelfingen//Germany. <hptt://www.bitzer.de 2014.

[11] Cecchinato L, Corradi M, Minetto S. Energy performance of supermarket refrigeration and air conditioning integrated systems. Applied Thermal Engineering. 2010 Oct 1;30(14-15):1946-58. https://doi.org/10.1016/j.applthermaleng.2012.04.049

[12] Centre for Energy Advancement through Technological Innovation (CEATI): Refrigeration system energy efficiency reference guide, $<$ hptt://www.ceati.com/freepublications/7044_guide_web.pdf $>2010$

[13] Devecioğlu AG, Oruc V. Characteristics of some new generation refrigerants with low GWP. Energy Procedia. 2015 Aug 1;75: 1452-7. https://doi.org/10.1016/j.egypro.2015.07.258

[14] Dincer I, Kanoglu M. Refrigeration systems and applications. New York: Wiley; 2010 May.

[15] Dixit M, Kaushik SC, Arora A. Energy and exergy analysis of absorption-compression cascade refrigeration system. Journal of Thermal Engineering. 2017; 3(5):1466-77. https://doi.org/10.18186/jte.42367

[16] Dixit M, Arora A, Kaushik SC. Energy and exergy analysis of a waste heat driven cycle for triple effect refrigeration. Journal of Thermal Engineering. 2016 Oct 1;2(5):954-61. https://doi.org/10.18186/jte.84533

[17] Esen H, Inalli M, Esen M. Technoeconomic appraisal of a ground source heat pump system for a heating season in eastern Turkey. Energy Conversion and Management. 2006 Jun 1;47(9-10):1281-97. https://doi.org/10.1016/j.enconman.2005.06.024

[18] Esen H, Inalli M, Esen M, Pihtili K. Energy and exergy analysis of a ground-coupled heat pump system with two horizontal ground heat exchangers. Building and environment. 2007 Oct 1;42(10):3606-15. https://doi.org/10.1016/j.buildenv.2006.10.014

[19] Fang Y, Croquer S, Poncet S, Aidoun Z, Bartosiewicz Y. Drop-in replacement in a R134 ejector refrigeration cycle by HFO refrigerants. international journal of refrigeration. 2017 May 1;77:87-98. https://doi.org/10.1016/j.ijrefrig.2017.02.028

[20] Honeywell, Solstice yf- a green solution to a global challenge, Cool for all concerned, $<\mathrm{hptt}: / / \mathrm{www}$.honeywell-refrigerants.com/Europe (2014)

[21] Honeywell, Solstice ze Refrigerants (HFO-1234ze), Low GWP hydrofluoroolefins(HFO), The environmental alternative to traditional refrigerants <hptt://www.honeywell-refrigerants.com (2015)

[22] Janković Z, Atienza JS, Suárez JA. Thermodynamic and heat transfer analyses for R1234yf and R1234ze (E) as drop-in replacements for R134a in a small power refrigerating system. Applied Thermal Engineering. 2015 Apr 5;80:42-54. https://doi.org/10.1016/j.applthermaleng.2015.01.041

[23] Zubair SM. Design and rating of an integrated mechanical-subcooling vapor-compression refrigeration system. Energy Conversion and Management. 2000 Jul 1;41(11):1201-22. https://doi.org/10.1016/S01968904(99)00169-7

[24] Klein, S. A., Alvarado, F.: Engineering Equation Solver. F Chart Software, Middleton, WI. Version 9. 2243D, 2012.

[25] Koeln JP, Alleyne AG. Optimal subcooling in vapor compression systems via extremum seeking control: Theory and experiments. International journal of refrigeration. 2014 Jul 1;43:14-25. https://doi.org/10.1016/j.ijrefrig.2014.03.012

[26] Kotas TJ. The exergy method of thermal plant analysis. Elsevier; 2013 Oct 22.

[27] Lemmon EW, Huber ML, McLinden MO. Reference Fluid Thermodynamic and Transport Properties, NIST Standard Reference Database 23, Version 9.0.

[28] Llopis R, Cabello R, Sánchez D, Torrella E. Energy improvements of $\mathrm{CO}_{2}$ transcritical refrigeration cycles using dedicated mechanical subcooling. International Journal of Refrigeration. 2015 Jul 1;55:129-41. https://doi.org/10.1016/j.ijrefrig.2015.03.016 
[29] Llopis, R, Sánchez, D, Sanz-Kock, C, Cabello, R, Torrella, E. Energy and environmental comparison of twostage solutions for commercial refrigeration at low temperature: Fluids and systems. Applied Energy. 2015 138:133 -142. https://doi.org/10.1016/j.apenergy.2014.10.069

[30] Maurizio A, Giovanni C. Power reduction in vapour compression cooling cycles by power regeneration. Energy Procedia. 2015 Dec 1;81:1184-97. https://doi.org/10.1016/j.egypro.2015.12.148

[31] Mota-Babiloni A, Navarro-Esbrí J, Barragán-Cervera Á, Molés F, Peris B, Verdú G. Commercial refrigeration-an overview of current status. International journal of refrigeration. 2015 Sep 1;57:186-96. https://doi.org/10.1016/j.ijrefrig.2015.04.013

[32] Mota-Babiloni A, Navarro-Esbrí J, Barragan A, Moles F, Peris B. Drop-in energy performance evaluation of R1234yf and R1234ze (E) in a vapor compression system as R134a replacements. Applied Thermal Engineering. 2014 Oct 5;71(1):259-65. https://doi.org/10.1016/j.applthermaleng.2014.06.056

[33] Mota-Babiloni A, Navarro-Esbrí J, Barragán-Cervera Á, Molés F, Peris B. Experimental study of an R1234ze (E)/R134a mixture (R450A) as R134a replacement. International Journal of Refrigeration. 2015 Mar 1;51:52-8. https://doi.org/10.1016/j.ijrefrig.2014.12.010

[34] Mota-Babiloni A, Navarro-Esbrí J, Barragán-Cervera Á, Molés F, Peris B. Analysis based on EU Regulation No 517/2014 of new HFC/HFO mixtures as alternatives of high GWP refrigerants in refrigeration and HVAC systems. International journal of refrigeration. 2015 Apr 1;52:21-31. https://doi.org/10.1016/j.ijrefrig.2014.12.021

[35] Pigani L, Boscolo M, Pagan N. Marine refrigeration plants for passenger ships: Low-GWP refrigerants and strategies to reduce environmental impact. International Journal of Refrigeration. 2016 Apr 1;64:80-92. https://doi.org/10.1016/j.ijrefrig.2016.01.016

[36] Qureshi BA, Zubair SM. Mechanical sub-cooling vapor compression systems: Current status and future directions. International journal of refrigeration. 2013 Dec 1;36(8):2097-110. https://doi.org/10.1016/j.ijrefrig.2013.07.026

[37] Qureshi BA, Inam M, Antar MA, Zubair SM. Experimental energetic analysis of a vapor compression refrigeration system with dedicated mechanical sub-cooling. Applied Energy. 2013 Feb 1;102:1035-41. https://doi.org/10.1016/j.apenergy.2012.06.007

[38] Regulation (EU) No 517/2014 of the European Parliament and of the Council of Fluorinated Greenhouse Gases and Repealing Regulation (EC), No 842/2006 (2014)

[39] Şahin AŞ. Performance analysis of single-stage refrigeration system with internal heat exchanger using neural network and neuro-fuzzy. Renewable energy. 2011 Oct 1;36(10):2747-52. https://doi.org/10.1016/j.renene.2011.03.009

[40] Sánchez D, Cabello R, Llopis R, Arauzo I, Catalán-Gil J, Torrella E. Energy performance evaluation of R1234yf, R1234ze (E), R600a, R290 and R152a as low-GWP R134a alternatives. International Journal of Refrigeration. 2017 Feb 1;74:269-82. https://doi.org/10.1016/j.ijrefrig.2016.09.020

[41] Sethi A, Becerra EV, Motta SY. Low GWP R134a replacements for small refrigeration (plug-in) applications. international journal of refrigeration. 2016 Jun 1;66:64-72. https://doi.org/10.1016/j.ijrefrig.2016.02.005

[42] She X, Yin Y, Zhang X. A proposed subcooling method for vapor compression refrigeration cycle based on expansion power recovery. International journal of refrigeration. 2014 Jul 1;43:50-61. https://doi.org/10.1016/j.ijrefrig.2014.03.008

[43] She X, Yin Y, Zhang X. Thermodynamic analysis of a novel energy-efficient refrigeration system subcooled by liquid desiccant dehumidification and evaporation. Energy conversion and management. 2014 Feb 1;78:286-96. https://doi.org/10.1016/j.enconman.2013.10.057

[44] Srinivas N, Deb K. Muiltiobjective optimization using nondominated sorting in genetic algorithms. Evolutionary computation. 1994 Sep;2(3):221-48. https://doi.org/10.1162/evco.1994.2.3.221

[45] Staicovici MD. A method of improving the effectiveness of a mechanical vapour compression process and of its applications in refrigeration. International journal of heat and mass transfer. 2011 Apr 1;54(9-10):175262. https://doi.org/10.1016/j.ijheatmasstransfer.2011.01.016

[46] Topal H, Taner T, Altinsoy Y, Amirabedin E. Application of trigeneration with direct co-combustion of poultry waste and coal: A case study in the poultry industry from Turkey. Thermal Science. 2018;22(6 Part B):3073-82. https://doi.org/10.2298/TSCI170210137T

[47] Topal H, Taner T, Naqvi SA, Altınsoy Y, Amirabedin E, Ozkaymak M. Exergy analysis of a circulating fluidized bed power plant co-firing with olive pits: A case study of power plant in Turkey. Energy. 2017 Dec 1;140:40-6. https://doi.org/10.1016/j.energy.2017.08.042

[48] Taner T. Optimisation processes of energy efficiency for a drying plant: A case of study for Turkey. Applied Thermal Engineering. 2015 Apr 5;80:247-60. https://doi.org/10.1016/j.applthermaleng.2015.01.076

[49] Taner T, Sivrioglu M. Energy-exergy analysis and optimisation of a model sugar factory in Turkey. Energy. 2015 Dec 15;93:641-54. https://doi.org/10.1016/j.energy.2015.09.007 
[50] Taner T, Sivrioglu M. A techno-economic \& cost analysis of a turbine power plant: A case study for sugar plant. Renewable and Sustainable Energy Reviews. 2017 Oct 1;78:722-30. https://doi.org/10.1016/j.rser.2017.04.104

[51] Xing M, Yan G, Yu J. Performance evaluation of an ejector subcooled vapor-compression refrigeration cycle. Energy Conversion and Management. 2015 Mar 1;92:431-6. https://doi.org/10.1016/j.enconman.2014.12.091

[52] Yang MH, Yeh RH. Performance and exergy destruction analyses of optimal subcooling for vaporcompression refrigeration systems. International Journal of Heat and Mass Transfer. 2015 Aug 1;87:1-0. https://doi.org/10.1016/j.ijheatmasstransfer.2015.03.085

[53] Yataganbaba A, Kilicarslan A, Kurtbaş İ. Exergy analysis of R1234yf and R1234ze as R134a replacements in a two evaporator vapour compression refrigeration system. International journal of refrigeration. 2015 Dec 1;60:26-37. https://doi.org/10.1016/j.ijrefrig.2015.08.010

[54] Yu J, Ren Y, Chen H, Li Y. Applying mechanical subcooling to ejector refrigeration cycle for improving the coefficient of performance. Energy Conversion and Management. 2007 Apr 1;48(4):1193-9. https://doi.org/10.1016/j.enconman.2006.10.009

[55] Zheng N, Zhao L. The feasibility of using vapor expander to recover the expansion work in two-stage heat pumps with a large temperature lift. International Journal of Refrigeration. 2015 Aug 1;56:15-27. https://doi.org/10.1016/j.ijrefrig.2014.11.010

[56] Zubair SM, Yaqub M, Khan SH. Second-law-based thermodynamic analysis of two-stage and mechanicalsubcooling refrigeration cycles. International Journal of Refrigeration. 1996 Nov 1;19(8):506-16. https://doi.org/10.1016/S0140-7007(96)00045-X 